\title{
PROFIT SHIFTING AND CORRUPTION
}

\author{
Katarzyna Bilicka* and André Seidel ${ }^{* *}$
}

This Version: 16.02.2020

\begin{abstract}
This paper introduces heterogeneous profit shifting costs induced by corrupt tax officials to the analysis of profit shifting of multinationals. Using a theoretically derived corruption weighted tax differential, we show that corruption increases profit shifting of European firms. We use our estimates to calculate the implied tax revenue elasticities for European countries and find that countries with otherwise similar tax rates face lower tax revenue elasticities when they are more corrupt. This means that corruption negatively affects the revenue gains that countries could have from increasing their tax rates.
\end{abstract}

JEL: H25, H26, D73

Keywords: corruption, profit shifting, tax revenue elasticities

\footnotetext{
* Utah State University, Jon M Hunstman School of Business, 3500 Old Main Hill, 34322 Logan, UT, USA and Oxford University Centre for Business Taxation,; katarzyna.anna.bilicka@gmail.com, corresponding author.

**University of Bergen, Department of Economics, P.O. 7802, 5020 Bergen, Norway; andre.seidel@uib.no.
} 


\section{INTRODUCTION}

The issues of tax evasion and tax avoidance have gained more attention in the political and economic debates since the revelations from Panama Papers and Paradise Papers. Since then, the OECD has extensively pushed to increase the country memberships in the Base Erosion and Profit Shifting (BEPS) initiative beyond the OECD borders. ${ }^{1}$ As a result, many Eastern European countries have started to implement the first stages of the BEPS action plan. However, weaker institutions are likely to be a large obstacle in the expansion of the BEPS initiative beyond the OECD borders. Different international organizations have repeatedly stated that corruption in tax administration $^{2}$ and the practice of revolving tax officials ${ }^{3}$ are serious threats to the ability of countries to enforce the collection of tax liabilities of multinational firms. Coupled with evidence that even large multinational companies are involved in straightforward corruption practices ${ }^{4}$, this raises a question of whether corruption in the tax administration may affect profit shifting decisions on multinational companies.

In this paper, we build a theoretical model in which a large multinational firm weights the costs of shifting profits against the benefits. The benefits include low tax rates. In the costs function, we introduce corruption in the tax administration. In our model governments have regulations to help them fight tax avoidance, i.e. to monitor the legal transfer of profits between countries. A firm that is involved in profit shifting devotes some time to comply with the country level regulations. In our model, these efforts are threatened by the possibility that firms may encounter corrupt tax officials. These officials can help them bypass the regulations or speed up the process in exchange for favors, such as, for instance, a position in the accounting division of the involved firm. This low-level corruption is virtually undetectable, hard to sanction and as result can be found even in the tax administration in highly developed countries. ${ }^{5}$ Our model predicts that this type of

\footnotetext{
${ }^{1}$ https://www.oecd.org/ctp/BEPSActionPlan.pdf

${ }^{2}$ See for example the joint report of IMF, OECD, UN and World Bank mandated at the G-20 Seoul for the G20 Summit (https://www.oecd.org/g20/summits/seoul/48993634.pdf)

${ }^{3}$ See for example the United Nations. Economic Commission for Africa (2015). Illicit financial flows: report of the High-Level Panel on illicit financial flows from Africa. Addis Ababa, page 35.

${ }^{4}$ The case of Glencore, which is a US-Swiss company, that has been involved in corruption activities in Congo is being investigated by the US Department of Justice. For details see: https://www.bloomberg.com/news/articles/2018-0703/glencore-gets-subpoena-from-u-s-regarding-money-laundering

${ }^{5}$ For instance, World Bank Enterprise Surveys (http://www.enterprisesurveys.org/data/exploretopics/corruption) report that the average percent of firms experiencing at least one bribe payment request is $3.5 \%$, while the average percent of firms expecting informal payment to public officials is $10.7 \%$ among the OECD countries. This implies a high level of informal bribery among the OECD countries. In contrast, for instance in Ukraine, these numbers are $50.4 \%$ and $73.1 \%$ and in Romania $9.8 \%$ and $18.7 \%$ respectively.
} 
corruption amplifies profit shifting of multinational firms. We find that the size of the effect of corruption on profit shifting depends on the amount of tax that can be saved shifting a unit of profit.

We test the predictions of the theoretical model by deriving a corruption adjusted tax differential (CTC). The model implies that companies with higher CTC should report lower profits in a given country. Using a panel of firm-level data on European companies, we show that multinationals report lower profits in affiliates that face higher levels of the CTC parameter. Using interaction effects model, we find that this effect is driven by both corruption and tax rate differences. The higher the corruption level in a given country, the larger is the effect of the tax rate differential on reported profits. Hence, our empirical results confirm that a) corruption amplifies profit shifting and b) that this effect increases in the tax rate differences that define the savings obtained by shifting a unit of profit.

Further, we use our findings to estimate tax revenue elasticities for European countries and find that accounting for corruption creates a much higher variation in the tax revenue elasticities then previous studies have indicated. Our empirical results imply that the more corrupt the country is, the larger the effect the tax rate differential will have on the firm's reported profits in this country. For example, in Italy an increase in the statutory tax rate by $1 \%$ creates approximately $7 \%-12 \%$ less tax revenue gain than in Norway. Without accounting for corruption, both countries would have almost the same tax revenue elasticity, since the statutory tax rate is $27.5 \%$ in Italy and $28 \%$ in Norway.

Our findings are novel to the literature on profit shifting and corruption, where most of the contributions analyze either the effects of taxes or the effects of corruption on firms' profits. In this paper we combine both strands of the literature to show how the effects of taxes on shifted profits are affected by the extent of corruption. Most of the theoretical contributions in the corporate tax literature use models where a profit-shifting firm has to weight the risk and the cost of hiding profits against the gains from the reduced tax burden (see for example Dischinger and Riedel (2011), Dharmapala and Riedel (2013) or Davies et.al. (2018)). The general agreement is that firms shift profits to affiliates in countries with lower corporate tax rates (Hines and Rice (1994), Desai et al. (2006)), especially to those located in tax havens (Gumpert et al. (2016), Dowd et al. (2017)). Firms use a variety of strategies to avoid paying corporate taxes, such as debt shifting (Desai et al. (2004), Huizinga el at. (2008)), transfer pricing (Cristea and Nguyen (2016), Davies et al. (2018)) and 
intellectual property location (Dischinger \& Riedel, 2011). In their metastudy, Heckemeyer and Overesch (2017) calculate the response of profits to tax rate differentials to find a tax semi-elasticity of subsidiary pre-tax profits of about 0.8 . The average magnitude of the estimates we present in this paper is in line with those semi-elasticities. However, we show that adding corruption generates a large heterogeneity in those semi-elasticities across countries.

The determinants of the costs of profit shifting are understudied in the literature. Bilicka and Fuest (2014) study information exchange between tax authorities and Johannesen et al. (2017) consider the effect of government quality on profit shifting. We present evidence that corruption may be another determinant of costs of profit shifting. More recently, Bilicka (2019), Torslov et al. (2018) and Jansky and Palansky (2019) measure the extent of profit shifting and show it is large. This suggests that the extent to which corruption can affect revenue elasticities may be large too.

In the corruption literature, until recently, collusion of tax payers and corrupt tax officials has only received the attention in theoretical models focusing on the interaction between income tax evasion and corruption (Chander \& Wilde, 1992; Besley \& McLaren, 1993; Flatters \& Macleod, 1995; Mookherjee \& Png, 1995; Hindriks, Keen, \& Muthoo, 1999; Marjit, Seidel, \& Thum, 2017). There are very few studies that examine the interaction of business tax evasion and corruption (Chen \& Chu, 2005; Crocker \& Slemrod, 2005; Seidel \& Thum, 2016). Recent empirical studies show that small and medium size firms do not necessarily suffer from corruption, as they benefit from tax evasion opportunities resulting from collusion with tax officials (Alm, Martinez-Vazquez, \& McClellan, 2016; Gauthier \& Goyette, 2014; Jagger \& Shively, 2015; Khan, Khwaja, \& Olken, 2016). Recently, corruption has received more attention in relation to profit shifting. Notably, Hebous and Lipatov (2014) consider the effects of corruption on the amount of investment concealed in tax havens. Our results show that, more generally, corruption affects the amounts of profits shifted by multinationals between countries, not necessarily just to tax havens.

\section{A Simple THEORY OF PROFIT SHIFTING AND CORRUPTION}

\subsection{The Costs of Profit Shifting In THe Presence of CorRuption}

A multinational group operates establishments in $n$ countries. ${ }^{6}$ Let us assume that the profit generated by an affiliate of the multinational in country $i \in[0, n]$ is $\pi_{i}$. The profit generated in

\footnotetext{
${ }^{6}$ Here, we assume that the allocation of profits across countries is given, along with the location choice of multinationals. In the Online Appendix B.3. we relax this assumption and show that our baseline results hold.
} 
country $i$ is taxed at the rate $t_{i}$. The multinational can shift the amount $S_{i}$ of profits in and out of country $i$. When $S_{i}>0$ the multinational shifts profits generated in country $i$ out and when $S_{i}<0$ it shifts profits generated somewhere else in. There exists a probability of being audited by a domestic tax official. These probabilities differ by countries depending on their regulatory environments and tax codes ${ }^{7}$; e.g. one in 100 firms gets audited by Internal Revenue Services each year in the United States ${ }^{8}$ Firms are audited after they submit their tax statement. The tax official has to evaluate whether the tax statement is in line with the tax responsibility of the firm defined by the domestic tax law and international transfer pricing agreements. During the auditing process, firms have to cooperate with the tax official and dedicate a substantial amount of time and effort to defend their tax statement. These auditing costs increase considerably when firms shift profits, for example because of increasingly complicated accounting rules and numerous debates on the interpretation of the tax law.

Following Hines and Rice (1994) and Huizinga and Laeven (2008), we assume that the positive costs of a tax audit induced by profit shifting are $\gamma \cdot S_{i}^{2} / \pi_{i}$, with $\gamma>0$ being a cost parameter. We therefore follow the assumption that "the marginal cost of shifting profits rises in proportion to the ratio of shifted profits to true profits” (Huizinga and Laeven (2008)). Hence, we assume that to accommodate profit shifting $S_{i}$ company's accounts have to be distorted relatively little, if true profits $\pi_{i}$ are relatively large. For simplicity, let us assume that a firm that does not shift profits does not face any auditing costs. Hence, auditing costs are always exclusively the result of profit shifting.

The tax official who audits a firm can be honest or corrupt. Let us assume that the corrupt tax official will never assist in tax evasion, as the risk of severe punishment is very high. ${ }^{9}$ However, he can offer to minimize the auditing cost in exchange for a bribe $B_{i} \cdot{ }^{10}$ Encountering a corrupt tax official may involve a cash payment or a more discreet type of bribe, such as giving small gifts

\footnotetext{
${ }^{7}$ https://www.oecd.org/tax/administration/37589900.pdf

${ }^{8}$ https://www.irs.gov/pub/irs-soi/17databk.pdf

${ }^{9}$ This assumption is relevant in low and middle-income European countries that we will consider in our empirical analysis. The punishment for assisting in tax evasion in those countries is high and the detection risk is also high, especially when multinational companies are involved. Note, that this may not hold in less developed countries.

${ }^{10}$ Corrupt tax officials could, despite the legality of tax avoidance, harass firms by threatening them to increase auditing costs in the case of non-cooperation. In the case of tax evasion Marjit, Mukherjee, and Mukherjee (2000) have shown that harassment does not influence the level of tax evasion. Harassment only allows corrupt tax official to extract more bribes from firms. Firms still profit from corruption in the tax administration. The same is true, if we allow for harassment in the case of tax avoidance. However, for simplicity of notation we abstain from this effect in our analysis.
} 
(e.g. concert tickets) or offering prospective employment in firms that are being audited. Despite extensive regulations, those practices are still prevalent in many highly developed European countries, such as Greece or Italy. ${ }^{11}$ Let us assume, for simplicity, that a corrupt tax official can decrease the auditing costs to zero. Therefore, when a firm meets a corrupt tax official the auditing costs can be zero, when the firm and the tax official come to an agreement. In contrast, when a firm that shifts profits encounters an honest tax official, it always faces the full auditing costs. Let us further assume, that tax officials face no tax auditing costs themselves and that there is no risk of detection and therefore punishment when making a deal with a corrupt official on both sides. ${ }^{12}$

We start the analysis with deriving the cost of profit shifting in the presence of corruption in the tax administration. ${ }^{13}$ We can write the payoffs $\left(\pi_{N B}\right)$ of a multinational affiliate that does not come to an agreement with a corrupt tax official or encounters an honest tax official as ${ }^{14}$

$$
\pi_{N B}=\left[\pi_{i}-S_{i}\right] \cdot\left[1-t_{i}\right]-\gamma \cdot \frac{S_{i}^{2}}{\pi_{i}} .
$$

We can write the payoffs $\left(\pi_{B}\right)$ of an affiliate that comes to an agreement with a corrupt tax official as

$$
\pi_{B}=\left[\pi_{i}-S_{i}\right] \cdot\left[1-t_{i}\right]-B_{i} .
$$

The negotiation between the corrupt tax official and the firm takes place in the form of Nash bargaining, with symmetric bargaining power. ${ }^{15}$ The firm and the corrupt tax official jointly maximize the benefits occurring from cooperation, which are defined as the differences between their utility from cooperation and non-cooperation. The joint optimization problem of a firm and a corrupt tax official is therefore:

\footnotetext{
${ }^{11}$ See for instance recent article from Financial Times (https://www.ft.com/content/9cd87756-269d-11e8-b27ecc62a39d57a0).

${ }^{12}$ This is a strong assumption. Introducing the risk of punishment would increase the amount of bribery. Depending on how the punishment is shared among the culprits the rent allocation would change and, in some cases, both parties would not reach an agreement. However, none of these affect the comparative statistics of the model as long as we do not assume non-liner punishment schemes.

${ }^{13}$ In the Online Appendix B.1 we consider how corruption outside of the tax administration affects the generation of profits in the first place.

${ }^{14}$ As in the previous literature (see for example Huizinga and Laeven (2008)), we assume that profit shifting costs as well as bribery costs are not tax deductible. This assumption helps to reduce the calculus substantially and does not change the main implications of the model.

${ }^{15}$ The main result of the model does not depend on the assumption of the specific form of bargaining or the distribution of the bargaining power. This is the case because for the bargaining to be successful the bribe always has to be smaller than the bureaucracy cost.
} 


$$
\max _{B_{i}}\left[B_{i}\right]^{\frac{1}{2}} \cdot\left[\pi_{B}-\pi_{N B}\right]^{\frac{1}{2}} .
$$

The solution to the maximization problem of the firm and the corrupt tax official is

$$
B_{i}^{*}=\frac{1}{2} \cdot \gamma \cdot \frac{S_{i}^{2}}{\pi_{i}} .
$$

The level of bribe increases in the size of auditing costs. From [1], [2] and [4] it follows that there is always a level of bribe a firm and the corrupt tax official can agree on, because $\pi_{N B}(S)<$ $\pi_{B}\left(S, B^{*}\right)$. Hence, when a firm meets a corrupt tax official, it will always pay a bribe. With probability $c_{i}$, a firm meets an honest official and with probability $1-c_{i}$ a corrupt tax official. Therefore, we will refer to $c_{i}$ as control of corruption. The expected costs of profit shifting are

$$
\frac{1}{2} \cdot\left[1+c_{i}\right] \cdot \gamma \cdot \frac{S_{i}{ }^{2}}{\pi_{i}} .
$$

From this, we can derive that with increasing control of corruption in the tax administration $\left(c_{i}\right)$, the cost of profit shifting increases.

\subsection{Profit SHIFTING AND CORRUPTION IN THE TAX ADMINISTRATION}

Taking the cost of profit shifting in the presence of corruption as given, the multinational has to decide how to allocate profits between affiliates, i.e. how much profits to shift in and out of each affiliate. From the previous assumptions and [5] we can derive the worldwide after-tax profits of a multinational.

$$
\Pi=\sum_{i=1}^{n}\left[\pi_{i}-S_{i}\right] \cdot\left[1-t_{i}\right]-\frac{1}{2} \cdot\left[1+c_{i}\right] \cdot \gamma \cdot \frac{S_{i}^{2}}{\pi_{i}}
$$

The multinational chooses the profit shifted $S_{i}$ to or from every affiliate to maximize the worldwide after-tax profits. Its maximization problem therefore is

$$
\max _{\forall S_{i}, \lambda} \Pi \sum_{i=1}^{n}\left[\left[\pi_{i}-S_{i}\right] \cdot\left[1-t_{i}\right]-\frac{1}{2} \cdot\left[1+c_{i}\right] \cdot \gamma \cdot \frac{S_{i}^{2}}{\pi_{i}}\right]-\lambda \sum_{i=1}^{n} S_{i}
$$

where $\lambda$ is the Lagrange multiplier. The first order conditions are given by

$$
\frac{\partial \mathcal{L}}{\partial S_{i}}=\left[-\left[1-t_{i}\right]-\left[1+c_{i}\right] \cdot \gamma \cdot \frac{S_{i}}{\pi_{i}}\right]-\lambda=0 \quad \forall S_{i} .
$$




$$
\frac{\partial \mathcal{L}}{\partial \lambda}=\sum_{i=1}^{n} S_{i}=0
$$

From [8] and [9] we can derive the amount of profits shifted in or out of affiliate $i{ }^{16}$

$$
S_{i}=\frac{\pi_{i}}{\gamma \cdot\left[1+c_{i}\right]} \cdot \Delta t
$$

where $\Delta t \equiv\left[\sum_{k \neq i}^{n} \frac{\pi_{k}}{\left[1+c_{k}\right]}\left[t_{i}-t_{k}\right]\right] \cdot\left[\sum_{k=1}^{n} \frac{\pi_{k}}{\left[1+c_{k}\right]}\right]^{-1}$. From this follows

$$
\frac{\partial S_{i}}{\partial \Delta t}=\frac{\pi_{i}}{\gamma \cdot\left[1+c_{i}\right]}>0
$$

Hence, if the tax rate in a country is relatively low, then multinationals most likely shift profits into that country. ${ }^{17}$ If the tax in a country is relatively high, then it is likely that multinationals shift profits abroad. This result is a common result in the previous theoretical and empirical literature on profit shifting (e.g. Hines and Rice (1994), Huizinga and Laeven (2008) or Fuest, Hebous, and Riedel (2011)). This result remains unchanged by accounting for corruption in the tax administation.

The question we are interested in is how corruption in the tax administration in the country where the affiliate is located influences profit-shifting behavior of that firm. Making use of [10], we obtain the following proposition.

Proposition 1. Increasing control of corruption in the tax administration of a country where an affiliate is located decreases profits shifted.

Proof: To see this we can derive from [10] the effect of an increase in the control of corruption in the tax administration on profits shifted.

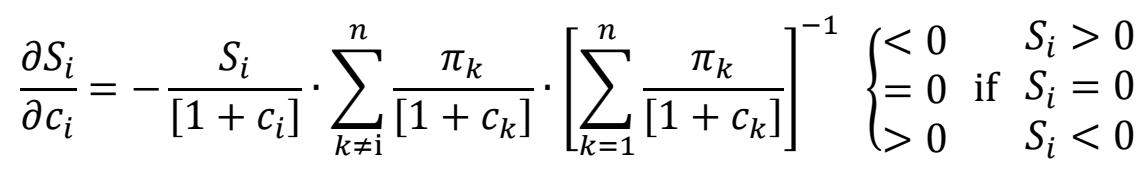

\footnotetext{
${ }^{16}$ For a detailed derivation, see the Online Appendix C.

${ }^{17}$ When we compare our model with one that does not account for corruption $\left(c_{i}=0\right)$, the marginal subsidiary for which the multinational is indifferent between shifting profits in or out may differ. This is the case because the firm faces a weighted tax differential. Hence, it may be that a multinational shifts profits into a subsidiary with a marginally higher tax rate than the average one, because the higher level of control of corruption in that country makes it more lucrative to keep profits there.
} 
From Proposition 1 it follows that a country with low control of corruption in the tax administration faces more profit shifting than a country with high control of corruption in the tax administration, when both have the same tax on profits. This is the case because the costs of profit shifting decrease with corruption. As a result, countries that, on average, receive profits from abroad may have no incentive to decrease the corruption in the tax administration. This is because as corrupt officials help reduce the transfer costs of profits, corruption may increase profit inflows and tax revenues. On the other hand, countries that, on average, lose profits because of profit shifting, may have a strong incentive to decrease this type of corruption. This may lead to a tax-enforcement competition between countries that should be addressed in future research. ${ }^{18}$

\subsection{EXTENDING THE SIMPLE THEORY}

The simple theory presented in this paper could be extended in several ways. In this section we discuss the modelling simplifications that make the model more tractable and the justifications for making those assumptions.

First, we do not account for the fixed costs of profit shifting. The model is set up in a way that firms can alter their profit transfers continuously when the tax rates change. This allows us to link the theoretical model to a dynamic setup in the data in which tax rates change over time. However, there is new, and emerging, literature arguing that firms may be facing fixed costs of profit shifting (Koethenbuerger et al. (2019), Bilicka et al. (2019)). Including fixed costs in our model does not alter the main mechanism. Corrupt officials and firms will still have an incentive to agree to collude, as long as there is a bribe that is smaller than the total costs of an audit. The size of shifted profits will be determined by the likelihood of meeting a corrupt official and the tax rate differential. The only difference is that in some instances, firms that would have transferred profits without the presence of fixed costs, may not do so now, if they think they are not likely to encounter a corrupt tax official. Consequently, the model would not predict a continuous effect of changes in tax rates and corruption on the amount of shifted profits. However, this will not affect the direction of the effects nor the mechanism presented in our theoretical section.

Second, we assume that profit shifting costs are equally borne both in the country that receives the shifted profits and the country than sends the shifted profits. This is in line with the findings of Becker and Davis (2014) who study how transfer prices are set. They conduct a series of interviews

\footnotetext{
${ }^{18}$ For a summary of the discussion on merits of tax competition, see Konrad and Stolper (2016).
} 
with tax authorities from high and low tax countries, employees at major accounting firms, and multinational firm managers. Relevant for our model are two of their findings. First, typically transfer prices are the outcome of negotiations between tax officials from both countries. Second, firms participate in this process by suggesting the 'right' transfer price in the country that is about to lose tax revenue and later by providing advice and legal support to the tax authorities in the country that receives those profits. Hence, there are costs to profit shifting on both ends of the transfer. For simplicity we do not model the negotiation between the tax authorities and assume that the transfer of profits in both directions is costly. ${ }^{19}$

Third, we do not distinguish between corruption in the country of origin and destination because the reasons for a bribe are the same in both cases. Firms pay bribes to reduce bureaucracy costs (red tape) associated with the paperwork linked to the legal processes of tax avoidance. Typically, both tax administrations are involved in the processes that leads to, for instance, setting a transfer price. During this process one tax administration is working to keep the profits in the country and the other to get them in. Bribes in both countries can help firms reduce the time and effort they must invest until both tax administrations come to an agreement.

We do not include a more elaborate model that accounts for those extensions for two reasons. First, we do not have the possibility to test specifics of such a model empirically. Second, this will not affect the direction of the effects nor the mechanism presented in our theoretical section.

\section{DATA AND ESTIMATION APPROACH}

\subsection{ESTIMATION APPROACH}

Using a panel of firm-level data on European companies, we aim to quantify the joint effect of taxation and corruption on profit shifting, i.e., we test Proposition 1. The challenge, however, is that profit shifting itself is typically ${ }^{20}$ not observable. We can only observe the reported profit of firms and therefore only indirectly test Proposition 1. Using [10] we can derive the expected reported profit of a multinational firm.

\footnotetext{
19 The model developed in this paper extends the basic idea that profit shifting cots occur on both ends of the transfer by accounting for corruption in tax administrations. However, this model is by far less sophisticated than the model of Becker and Davies.

20 Most studies use, as we do, accounting data, hence, they only indirectly study profit shifting. One of the few noteworthy exceptions are the recent studies by Bilicka (2019) and by Davies et. al. (2018) that utilize confidential corporate tax returns datasets to measure the extent of profit shifting directly.
} 


$$
R \pi_{i}=\pi_{i}\left[1-\frac{\Delta t_{i}}{\gamma \cdot\left[1+c_{i}\right]}\right]
$$

After taking the logs, we can approximate this to obtain

$$
\log \left(R \pi_{i}\right)=\log \left(\pi_{i}\right)+\log \left[1-\frac{1}{\gamma} \cdot C T C_{i}\right] \approx \log \left(\pi_{i}\right)-\frac{1}{\gamma} \cdot C T C_{i}
$$

where

$$
C T C_{i} \equiv \frac{\Delta t_{i}}{\left[1+c_{i}\right]}
$$

The variable $C T C_{i}$ is a composite tax and corruption variable that reflects how tax and corruption drive profit shifting. It is a corruption adjusted tax differential. The true profit of a firm $\pi_{i}$ as well as the corruption adjusted tax differential $C T C_{i}$ cannot directly be observed given the data available. Hence, we need to find proxies for both determinants of the reported profits.

\section{Approximating the CTC Parameter}

To calculate the composite tax and corruption parameter (CTC) for all affiliates of a multinational firm we have to make some simplifications, mainly because of data availability. For this, we will use the well-known results from the previous empirical literature that are not accounted for by our theoretical analysis.

First, we do not know the true profit of all affiliates of a multinational company ${ }^{21}$. Therefore, we cannot, as the theory suggests, calculate size- or sales- weighted multinational average tax rates. This is a common problem in the empirical literature that focuses on the extent of profit shifting of European firms. ${ }^{22}$ Hence, following Dischinger and Riedel, (2011) we make a simplifying assumption that each subsidiary has equal weight, so that $\Delta t$ becomes $t_{i}-\frac{1}{n} \sum_{k \neq i}^{n} t_{k}$.

Second, the profit shifting literature often makes a case that it becomes more difficult to shift profits to affiliates further away in the company ownership tree. This may, for example, arise because firms that are direct subsidiaries have trade relationships in the form of exchange of upstream

\footnotetext{
${ }^{21}$ This is the case since we only have firm level data for European firms. We know that this particular firm has affiliates in other countries, but we do not have detailed accounting information for many of those affiliates.

${ }^{22}$ See for example Huizinga and Laeven, (2008); Dischinger and Riedel, (2011); Dharmapala and Riedel, (2013) or Beer and Loeprick (2015). Similar to Huizinga and Laeven (2008) we could construct a sales-weighted or sizeweighted corruption adjusted tax rate differential for a subsample of companies for which we have information on sales or assets of majority of their subsdiaries. This substantially limits our sample. However, similarly to Dischinger and Riedel (2011) when doing this, we find that the application of weighted differentials leads to qualitatively comparable results. These are available from the authors upon request.
} 
products. In such cases profit shifting could occur by manipulating transfer prices of these existing transactions, which may decrease the cost of shifting profits. ${ }^{23}$ Hence, firms may be more willing to shift profits to either parent company or closest subsidiary. In the empirical section we use this information to construct three different definitions of what constitutes a group of related affiliates. Subgroup A contains all firms that belong directly to the same Global Ultimate Owner (GUO) and the GUO itself; subgroup B contains all subsidiaries of the firm and its GUO and subgroup C contains all firms that have the same GUO as the observed firm. Figure 4 in the Appendix illustrates the definitions of the three subgroups.

Third, and related, previous literature suggests that multinational firms cannot or do not want to shift profits between all their affiliates. For example, there is evidence that multinationals tend to accumulate profits in their headquarters (Dischinger, Knoll, \& Riedel, 2014) that cannot be explained by tax differences alone. On the other hand, if a multinational has an affiliate in a tax haven country, profits may always be shifted directly to the tax haven (Dowd, Landefeld, \& Moore, 2017), subject to Controlled Foreign Company (CFC) rules. ${ }^{24}$ This would mean that the tax rates of other affiliates of that multinational are not relevant. ${ }^{25}$

Given these considerations we use three different measures to approximate for $\Delta t_{i} \cdot{ }^{26}$ First, we define $\Delta t_{A V, m} \equiv t_{i}-\tau_{A V, m}$, where $\tau_{A V}$ is the un-weighted average of the tax rate of all affiliates belonging to subgroups $m$. Here subgroup $m$ takes values A, B or C as defined above. Second, using the idea that "there is no such place as home", we define $\Delta t_{H Q} \equiv t_{i}-\tau_{H Q}$ where $\tau_{H Q}$ is the tax rate at the multinational firms headquarter (HQ). Third, given a large discussion in the literature on the existence and use of tax havens we define $\Delta t_{H A V E N}$ that is 1 when a tax haven is part of the multinational firm structure and is otherwise 0. We define tax haven, following Hines and Rice (1994) as a country on the OECD tax haven list. ${ }^{27}$

\footnotetext{
${ }^{23}$ Davies et.al. (2018) for example, shows that the bulk of tax loss from transfer prices manipulation in France is coming from the actions of a few closely linked multinational firms.

${ }^{24}$ The CFC rules are anti-avoidance provisions designed to prevent diversion of profits to low tax territories. For instance, if the UK profits are diverted to a CFC, those profits are apportioned and charged to a UK corporate interestholder that holds at least a $25 \%$ interest in the CFC.

${ }^{25}$ For a detailed discussion on the use of tax haven affiliates, see for example Desai, Foley and Hines (2004) or more recently Gumpert, Hines and Schnitzer (2016).

${ }^{26}$ Tax rates data are taken from the CBT Tax Database.

${ }^{27}$ For the list of tax havens used in this paper see Table 7 in the Appendix.
} 
Making use of these different definitions of $\Delta t$ and [14] we obtain five different approximations for the CTC index, $C T C_{H Q}, C T C_{A V . A}, C T C_{A V . B}, C T C_{A V, C}$ and $C T C_{H A V E N}$. For those CTC parameters, which vary at the firm level, corruption is always measured on the country level. Table 5 in the Appendix shows descriptive statistics related to the tax difference parameters.

\section{Approximating the Profitability of a Firm}

Following Hines and Rice (1994) and Huizinga and Laeven (2008), we assume that true profit is the return on capital. Capital $K_{i}$ and labour $L_{i}$ are jointly employed by the firm to produce output $Q_{i}$. Output generated can be approximated by a Cobb-Douglas production function given by $Q_{i}=A_{i} \cdot L_{i}^{\alpha} \cdot K_{i}^{\varphi} \cdot e^{u_{i}}$ where the variable $A_{i}$ is a productivity parameter and $u_{i}$ is a random term. The profit generated by the firm is defined as output minus the wages paid, hence $\pi_{i}=Q_{i}-$ $w_{i} \cdot L_{i}$. We assume that the wage $w_{i}$ is equal to the marginal product of labour that is $w_{i}=\alpha \cdot A_{i}$. $L_{i}^{\alpha-1} \cdot K_{i}^{\varphi} \cdot e^{u_{i}}$. Therefore the generated profit can be approximated by

$$
\pi_{i}=[1-\alpha] \cdot A_{i} \cdot L_{i}^{\alpha} \cdot K_{i}^{\varphi} \cdot e^{u_{i}} .
$$

Making use of this and taking the logs of [15], we get

$$
\log \left(\pi_{i}\right)=\log (1-\alpha)+\log (A)+\alpha \cdot \log \left(L_{i}\right)+\varphi \cdot \log \left(K_{i}\right)+u_{i}
$$

Substituting in [13] $\log \left(\pi_{i}\right)$ we get the following equation that we will be estimating

$$
\log \left(R \pi_{i}\right)=\beta_{1}+\beta_{2} \cdot \log \left(A_{i}\right)+\beta_{3} \cdot \log \left(L_{i}\right)+\beta_{4} \cdot \log \left(K_{i}\right)+\beta_{5} \cdot C T C_{i}+u_{i} .
$$

where $\beta_{1}=\log (1-\alpha), \beta_{3}=\alpha, \beta_{4}=\varphi$ and $\beta_{5}=-\frac{1}{\gamma}$. From, Proposition 1 and [10] we expect $\beta_{5}$ to be significant and negative.

We estimate this equation using OLS and we include fixed assets and employment as time variant firm level controls for production function inputs, where the proxy for capital is log of fixed assets and the proxy for labor inputs is log of the number of employees ${ }^{28}$. We further include time variant macro variable characteristics, such as GDP per capita and development level of a country. This enables us to tease out the effects of tax and corruption rather than specific time varying country characteristics. Furthermore, the development level of a country might also influence firm-level productivity.

${ }^{28}$ Alternative robustness specifications include logs of wages instead (results available upon request from authors). 
Finally, in order to account for unobserved time and firm level heterogeneities we include year and firm fixed effects in the estimated equation. Tax differences to headquarters and to average tax within the multinational group vary within firms and between years. This is the variation we explore to identify the effects of the CTC parameter on firm's profits. ${ }^{29}$ Only for the estimations with $\Delta t_{H A V E N}$ we forgo using firm fixed effects and use country fixed effects instead. This is because the tax haven dummy is constant over time within each firm due to the cross-sectional nature of the ownership database. Therefore, in those regressions the identification comes from changes in the CTC parameter within countries and over time.

\subsection{DATA AND SAMPLE SELECTION}

\section{Accounting data}

To test the theoretical predictions of the model we use the firm level accounting data from the AMADEUS database provided by Bureau van Dijk. ${ }^{30}$ The dataset includes unconsolidated and consolidated balance sheets and income statements of European companies in the years 2005 2013. We use this data to obtain the firm level reported profits as the main variable of interest in our empirical analysis. Specifically, we use unconsolidated firm level data on profit and loss before tax. We also use fixed assets and employment data as proxies for capital and labour inputs.

Since we consider companies with the ability to shift profits abroad, we limit our sample only to multinational companies, i.e. those firms that have affiliates abroad. Amadeus data provides us with information on ownership structure of companies, which enables us to identify multinational and domestic companies. We define a multinational as a company that has a foreign global ultimate owner or one of its subsidiaries (up to level 10) is located abroad. We also supplement that with the information on whether the global ultimate owner of that company has any foreign subsidiaries even if the company itself might not. To identify multinational companies from the domestic companies, we use ownership information where the affiliate is owned or owns more than $50 \%$ of the company. ${ }^{31}$ Importantly, even though our data only has detailed accounting information for the European multinational affiliates, we have ownership information on subsidiaries and headquarters

\footnotetext{
${ }^{29}$ Since our identification comes from differences in tax rates over time our results are not directly comparable to Huizinga and Laeven (2008), who use a cross sectional variation in weighted tax rate differentials to show the effects of those on profit shifting. Our results are more comparable to work of Dischinger and Riedel (2011) who use a similar firm-fixed effects specification. In their estimations, the unweighted average tax rate differential affects the ratio of intangible profits to sales negatively, which is what we find as well for profits. The magnitude of the effect is comparable as well; for the results see Table 1, column 1.

${ }^{30}$ Table 3 in the Appendix presents detailed information on all data sources used.

${ }^{31}$ We experiment with $90 \%$ and wholly owned thresholds as well, but they do not change the main results of the paper.
} 
located anywhere in the world. The ownership information is time invariant and most of it refers to ownership status as of 2013, i.e. it comes from the most recent version of the AMADEUS dataset we have. We assume that if the company has foreign affiliates now, it had them before as well, which is a limitation of our data. This means that we are unable to identify changes in ownership patterns over time.

The whole Amadeus dataset contains information on 29 million firms over the sample period. Out of those 29 million firms, we have unconsolidated firm level information on 400,000 multinational affiliates for which we remove missing observations for all the variables of interest. Furthermore, we remove top and bottom $1 \%$ of the sample distribution to control for the presence of outliers. Implicitly, we will exclude affiliates that have negative profit and loss before tax, fixed assets or cost of employees, since we run all the regressions in natural logarithms ${ }^{32}$. After cleaning, the dataset has 757,127 observations that describe 190,070 firms. Table 4 in the Appendix summarizes the main variables of interest.

\section{Corruption indicators}

Measuring corruption is inherently difficult, because corruption captures the extent to which public power is exercised for private gain and that is unobservable. In this paper, we use two different types of corruption indicators to approximate for the effects of corruption on profit shifting. In the baseline estimation we use the well-established world governance indicator (WGI) provided by the World Bank. In the robustness analysis, we use the World Bank Enterprise Survey (WBES). We discuss each in turn.

WGI is a summary measure of control of corruption based on several different sub-indicators. These sub-indicators refer to perceptions of corruption by various groups of respondents, such as individuals, firms, nongovernmental agencies, commercial business information providers and public-sector organizations. ${ }^{33}$ The WGI control of corruption index captures all years and countries in our firm level data sample. Relative to the other widely used perception of corruption indicator, Transparency International Corruption Perception Index (CPI), WGI has two main advantages. First, it improves the CPI methodology, as it draws on substantially more data sources and is

\footnotetext{
${ }^{32}$ In the light of recently emerging evidence on the importance of reporting zero profits for the extent of multinational profit shifting (see Bilicka, 2019), we will show that our results are robust to the inclusion of negative profits.

${ }^{33}$ The underlining definition of corruption that is used to select the different sub-indicators is: Control of Corruption, measuring the exercise of public power for private gain, including both petty and grand corruption and state capture (Kaufmann, Kraay, \& Mastruzzi, 2005, p. 5).
} 
therefore less likely to be biased by the perception of a handful of experts (for more details see Kaufmann et al. 2005). ${ }^{34}$ Second, the WGI includes other indicators of governance quality that we can use to rule out the possibility that our results are driven by overall institutional differences rather than corruption in particular (Johannesen, Tørsløv, \& Wier, 2017). However, the limitation of this indicator is that the propensity to collect taxes is only one of the dimensions of corruption captured by the WGI index. The index also captures several other forms of corruption. When using the WB index, we therefore implicitly assume that corruption is a systematic phenomenon. Hence, if there is a change in one type of corruption, there is usually also a change in the other.

In the cross-section the WGI measure of control of corruption is strongly correlated with other government quality indicators ( $0.75-0.9$ correlations are typical). However, comparing the development of the governance indicators over time reveals that their movements over time are not highly correlated. The correlation between changes over time in control of corruption and changes over time in other governance indicators varies from 0.08 for political stability to 0.358 for government effectiveness. Further, the standard deviation in the control of corruption measure over time displays low correlations with Regulatory Quality (0.33), Government Effectiveness (0.46), Voice and Accountability (-0.07) and Political Stability (0.30). This suggests that our results are likely to be related to changes in the control of corruption and not to changes in other governance indicators. ${ }^{35}$

The second measure of control of corruption we use, WBES, is an indicator that comes from the World Bank survey of firms that has been run since 2005. The question we use as an indicator for corruption in the tax administration is "percent of firms expected to give gifts in meetings with tax officials". This means that the results using WB survey indicator as a proxy for corruption can be more directly attributed to control of corruption in the tax administration, rather than corruption outside of tax administration or general quality of the government institutions. However, the disadvantage of using the WB Survey Indicators is that our sample decreases considerably; the indicator is not available for all the countries in our sample and the survey has not been conducted

\footnotetext{
${ }^{34}$ We have run the main specifications with the CPI indicators and the qualitative results remain unchanged, but the point estimates vary slightly, mostly due to a slightly different sample composition.

${ }^{35}$ In the Online Appendix B.2, we test the validity of these claims by including in the baseline model interactions with various governance indicators in addition to interactions with control of corruption. In majority of the specifications, the control of corruption interaction with tax rate differential is significant, while the other governance indicator interaction is not. This suggests that out main results are driven by changes in control of corruption rather than overall changes in governance quality.
} 
yearly, hence, we do not have a full balanced panel for the indicator. ${ }^{36}$. In the years when the WB Survey has been conducted the correlation between the two corruption indicators, we use is very high and ranges between 0.7 and 0.93 suggesting that these two measures are strongly related to each other.

\subsection{IDENTIFYING VARIATION}

Using CTC allows us to account for the joint effect of the tax rate differential and the level of corruption on profit shifting. Since our main specification is a firm fixed effects regression, we rely on the variation in both tax rate differentials and corruption levels over time to identify the effects of the CTC parameter on profit shifting. In this section we discuss how CTC and each of the components of the CTC parameter evolve over time.

Corruption is often described to be very persistent over time, which is why there is a debate about the capability of the existing corruption indicators to capture changes in corruption over short time periods. To show that this is not the case during the analyzed sample period, Figure 1 (left) shows the control of corruption as reported by the WGI in 2013 on the horizontal axis with the control of corruption reported in 2005 on the vertical axis. We can clearly see that control of corruption has changed in most of the countries over the analyzed time period and that the direction of the change is either for the worse or the better. The further away from the 45-degree line the country is, the larger the change in corruption; countries such as Lithuania or Macedonia have recorded the largest increases in control of corruption between 2005 and 2013, while Greece and Slovakia have recorded largest decreases in control of corruption.

${ }^{36}$ For the list of countries and mean values of corruption indicators see Table 7 in the Appendix. 


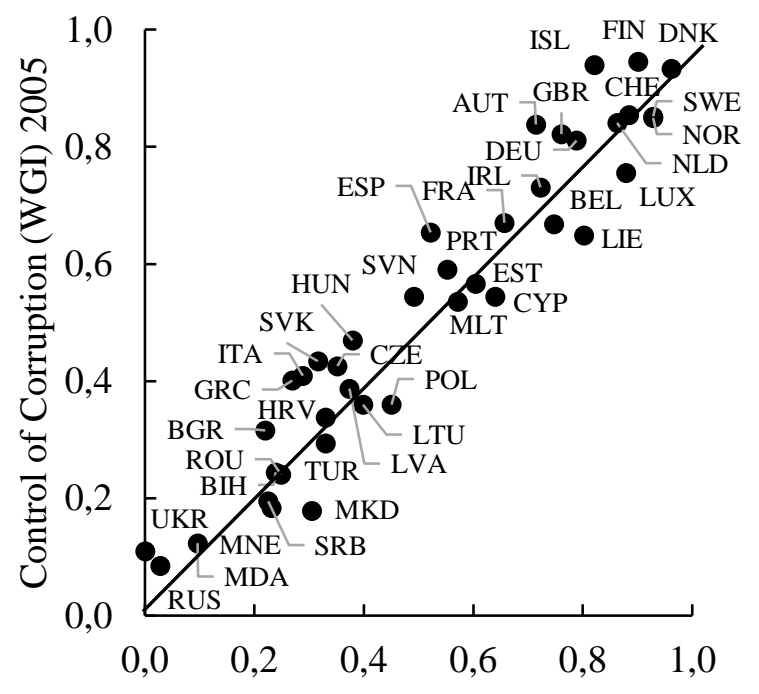

Control of Corruption (WGI) 2013

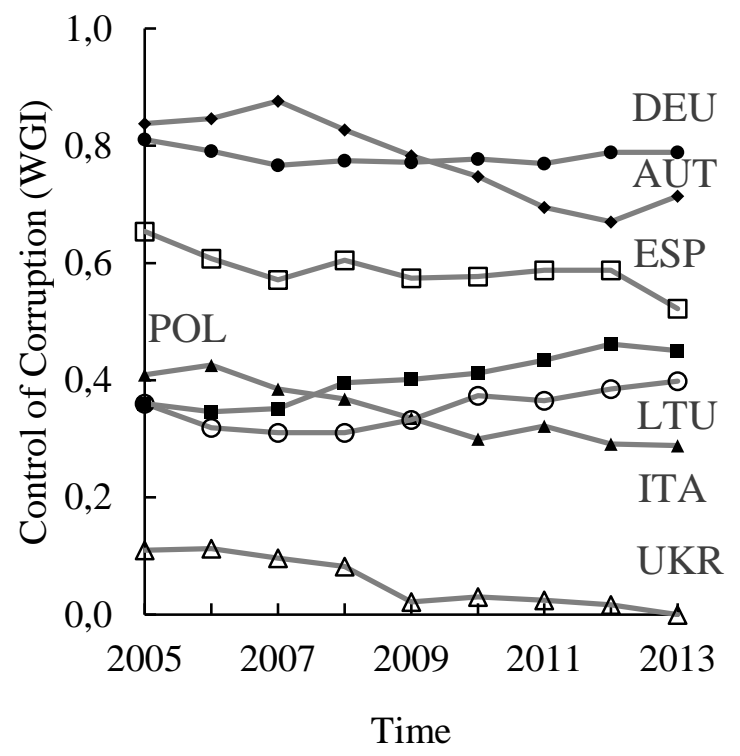

Figure 1 Change of Control of Corruption (WGI) over time

When we consider yearly changes in control of corruption for selected group of countries (Figure 1, right) we can identify several large changes in the control of corruption within these countries between years e.g. Ukraine from 2008 to 2009, Spain from 2012 to 2013, Poland from 2007 to 2008 or Austria from 2007 to 2012. We also see that in some countries the change in corruption is never meaningful; e.g. Germany. ${ }^{37}$

The second source of variation in the CTC parameter comes from changes in tax rate differentials over time. Note that these changes occur at the firm level. Figure 2 illustrates for some selected affiliates of multinational companies located in different countries, the evolution over time of the tax rate differentials to their headquarters $\Delta t_{H Q}$ (left) and tax rate differentials to the average among the other affiliates $\Delta t_{A V, C}$ (right). Like the corruption indicator, tax rate differentials are in some instances also fairly persistent. For example, for the subsidiaries located in Italy, the tax rate differences to their headquarter have remained virtually unchanged over the time period. On the other hand, for the subsidiaries located in Spain, Poland, Lithuania or Ukraine the tax rate differences to their headquarters have changed substantially over the sample period (Figure 2, left). As expected, the changes in the tax rate differentials over time are more pronounced when we

\footnotetext{
${ }^{37}$ Note that the changes in corruption are often correlated with the reforms effort. For instance, upon EU accession Poland has reformed its Anti-Corruption Policy, which is visible in the increasing control of corruption index from 2004 onwards. Further, Austria has introduced a package of anti-corruption reforms in 2012 in response to the falling levels of control of corruption; this has generated an immediate rebound in the corruption perception index in 2013.
} 
consider the differences between the domestic tax rate and the un-weighted average of all the tax rates faced by the other affiliates of the multinational firm (Figure 2, right). Here, we can see yearly tax differential changes for affiliates in all countries. The comparison between the two panels in Figure 2 also highlights the importance of using various definitions of tax rate differentials. For instance, the affiliate located in Spain has on average faced a decrease in the gap between its tax rate and the tax rate of its headquarter, while the tax rate gap relative to the average of all the subsidiaries of the multinational company was more stable (apart from 2013).

Taken together Figures 1 and 2 show, that there exists a substantial variation in both corruption levels and tax rate differentials to identify the effects of the CTC parameter on profit shifting. It is important to note that tax rate changes on the country level as well as tax rate differential changes over time are not correlated with corruption changes. The correlation between statutory tax rate changes and control of corruption changes in countries where affiliates are located is almost zero $(-0.007)$, similar to the correlation between changes in the tax rate differentials and changes in control of corruption (-0.02 for changes to the average tax rate differentials and -0.006 for changes to the headquarter tax rate differential). This makes us confident that the changes in the CTC parameter are driven by both corruption and tax rate differential changes, rather than strictly by tax rate differentials, as has been shown by the previous literature.
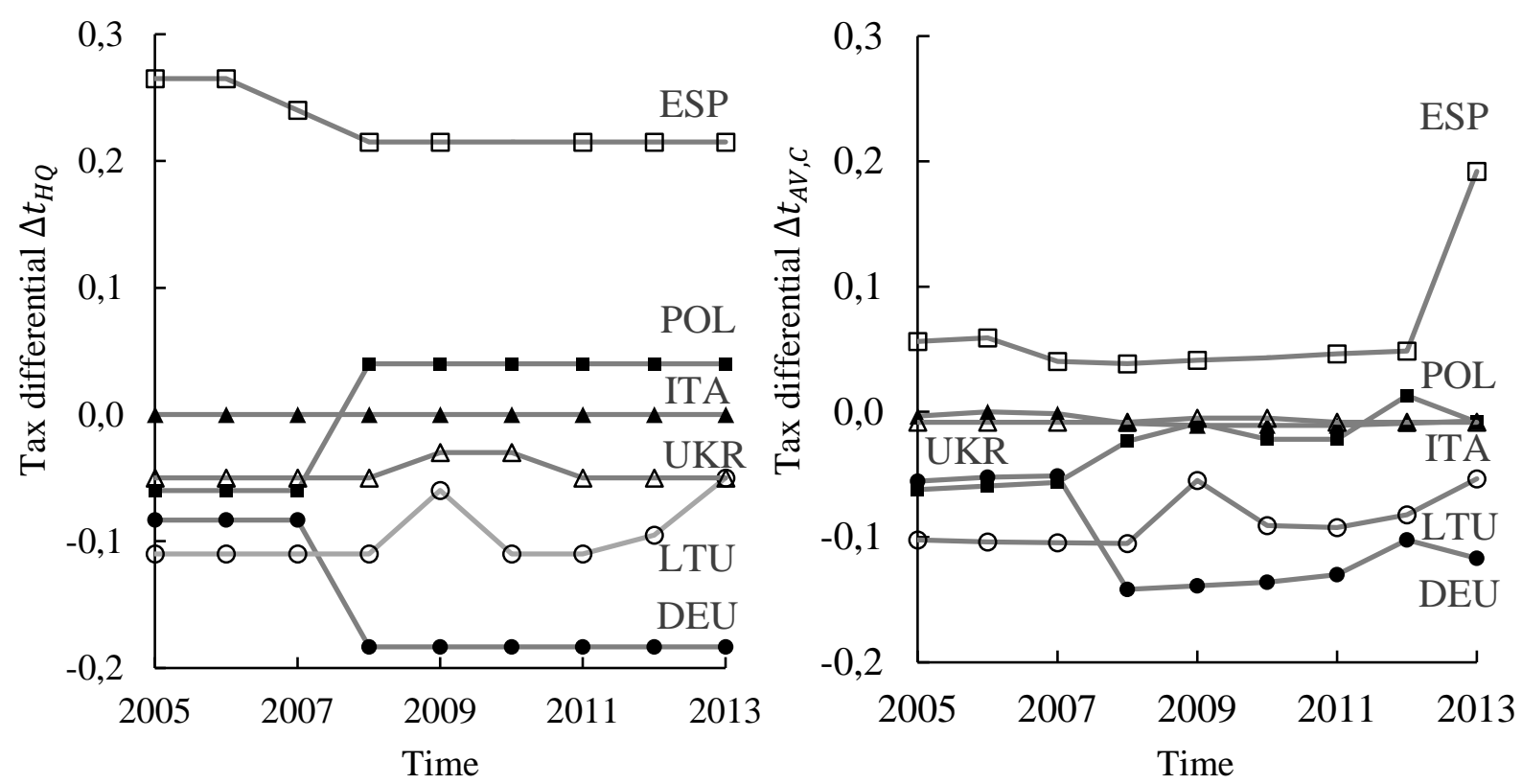

Figure 2 Change in tax rate differentials over time. 


\section{RESULTS}

\subsection{REPORTED PROFITS}

Table 1 shows the baseline results using equation [17] and various definitions of the CTC parameter as outlined in Section 3.1. First, in column 1 we present results with the tax rate differential which is not adjusted for corruption. We use the average tax rate that includes all affiliates linked to the multinational headquarter (definition C). This is how the previous literature on profit shifting estimated the responses of reported profits to changes in the tax rate differential. We find the coefficient on the tax rate differential to be 0.52 . Heckmeyer and Overesch (2017) show in their meta-study that the estimate of this semi-elasticity is 0.8 on average. One of the most influential early studies by Huizinga and Leaven (2008) using European multinationals and a cross sectional variation in tax rate differential finds the semi-elasticity to be 1.3. Generally, estimates using panel data and affiliate fixed effects are considerably smaller than those found by Huizinga and Leaven (2008) (see discussion by Dharmapala (2014)). For instance, Dischinger et al. (2014) show that the average semi-elasticity of profits in Amadeus data is 0.7, while Lohse and Riedel (2013) use more recent data to show that this semi-elasticity is 0.4. Considering that we use Amadeus data in our study, our coefficients are comparable to the latter two studies and their magnitudes are in line with what the previous literature has shown.

In columns $2-6$ we investigate the effects of the theoretically derived corruption adjusted tax rate differential on the reported profits of multinational companies. Column 2 uses the average tax rate that includes all affiliates linked to the multinational headquarter (definition C), columns 3 looks at the average tax rate defined by the HQ and all of subsidiaries of the observed firm (definition B), while column 4 looks at the average tax rate of all firms with direct link to the HQ (definition A). Column 5 uses the difference in the tax rate of the firm to its HQ and column 6 uses the tax haven dummy as a measure of the extent of profit shifting incentives. From the theory we expect the CTC parameter to be significant and negative and that is the case throughout the estimations, irrespective of what definition of the tax difference we use to construct the parameter. 
TABLE 1 THE EFFECT OF CORRUPTION AND TAXATION ON REPORTED PROFITS.

\begin{tabular}{lllllll}
\hline \multirow{2}{*}{ Definitions of CTC } & $(1)$ & $(2)$ & $(3)$ & $(4)$ & $(5)$ & $(6)$ \\
& $C T C_{A V, C}$ & $C T C_{A V, C}$ & $C T C_{A V, B}$ & $C T C_{A V, A}$ & $C T C_{H Q}$ & $C T C_{H A V E N}$ \\
capital & & & & & & \\
& $0.070^{* * *}$ & $0.070^{* * *}$ & $0.070^{* * *}$ & $0.070^{* * *}$ & $0.070^{* * *}$ & $0.199^{* * *}$ \\
labour & $(0.003)$ & $(0.003)$ & $(0.003)$ & $(0.003)$ & $(0.003)$ & $(0.002)$ \\
& $0.332^{* * *}$ & $0.330^{* * *}$ & $0.330^{* * *}$ & $0.330^{* * *}$ & $0.330^{* * *}$ & $0.430^{* * *}$ \\
$\ln (\mathrm{GDPpc})$ & $(0.006)$ & $(0.006)$ & $(0.006)$ & $(0.006)$ & $(0.006)$ & $(0.003)$ \\
& $1.157^{* * *}$ & $1.177^{* * *}$ & $1.185^{* * *}$ & $1.177^{* * *}$ & $1.184^{* * *}$ & $1.184^{* * *}$ \\
$\Delta t$ & $(0.050)$ & $(0.051)$ & $(0.051)$ & $(0.051)$ & $(0.051)$ & $(0.051)$ \\
& $-0.520^{* * *}$ & & & & & \\
CTC & $(0.120)$ & & & & & \\
& & $-0.972^{* * * *}$ & $-1.649 * * *$ & $-0.986^{* * *}$ & $-0.981^{* * *}$ & $-0.129 * * *$ \\
Constant & & $(0.191)$ & $(0.246)$ & $(0.180)$ & $(0.135)$ & $(0.015)$ \\
& $-8.468^{* * *}$ & $-8.676^{* * *}$ & $-8.765^{* * *}$ & $-8.681^{* * *}$ & $-8.752^{* * *}$ & $-9.491 * * *$ \\
& $(0.531)$ & $(0.538)$ & $(0.538)$ & $(0.538)$ & $(0.538)$ & $(0.533)$ \\
\#Obs. & & & & & & \\
\#Firms & 613,593 & 605,399 & 605,399 & 605,399 & 605,543 & 716,539 \\
R-squared & 153,780 & 152,997 & 152,997 & 152,997 & 153,050 & 181,359 \\
\hline
\end{tabular}

Note: Dependent variable: $\ln (\mathrm{pbt})$, Standard errors are clustered at the corporate group and country level, $\left({ }^{* * *}\right) \mathrm{p}<0.01$, ${ }^{(* *} \mathrm{p}<0.05$, (*) $\mathrm{p}<0.1$. Columns (1) and (2) use $\Delta t_{A V, C}$, column (3) uses $\Delta t_{A V, B}$, column (4) $\Delta t_{A V, A}$, column (5) $\Delta t_{H Q}$ and column (6) $d \triangle t_{H A V E N}$ as a proxy for tax rate difference in the calculation of $C T C$. All estimates include firm and year fixed effects except column (6) that uses country and year fixed effects.

These results are consistent with Proposition 1 under the assumption the corruption index used here is a good proxy for corruption in tax administration. We show that increasing CTC decreases profits reported by an affiliate. The coefficient estimates for CTC are quite stable when comparing the results with firm fixed effects in columns $2-5$.

To interpret these coefficients, let us consider the result from Column 2. Here, an increase in the CTC parameter by one unit leads to a decrease in the firm’s reported profit by approximately 97\%. Considering that the standard deviation in the CTC parameter is 0.027 (see Table 5 in the Appendix), this implies that a standard deviation change in the CTC parameter leads to a 2.6\% decrease in the firm's reported profit. This implies a large and highly significant joint effect of taxes and corruption on reported profits.

Further, the theory model tells us that $\hat{\beta}_{5}$ should proxy for $-1 / \gamma$. Hence, using the estimated coefficient on $\hat{\beta}_{5}$ and the range of $C T C_{A V, C}$ we can calculate the implied maximum and minimum 
size of the CTC effect (that is identical to the share of true profits shifted) on the profits reported by a firm in our sample. Using [12] and $\hat{\beta}_{5}=-0.972$ implies that the effect of CTC parameter on profits varies between $-19 \%$ and $16 \%{ }^{38}$

Table 2 addresses several concerns related to the baseline results. Column 1 uses a different measure of corruption, column 2 considers the case of negative profits, column 3 uses a firm specific measure of corruption to adjust the tax rate differential in the CTC parameter, while columns 4 - 6 analyze to what extent the effect of the CTC parameter on reported profits is driven by both tax and corruption.

The results from Column 1 are directly comparable to those from Column 2 in Table 1 as we use the same measure of tax differential here. The only difference is that we now use the WB Survey indicator to approximate for corruption. Despite the substantial decrease in the samples size, our main result remains significant. The CTC parameter negatively and significantly affects the reported profits of firms. The magnitude of the effect is larger, and in this smaller sample, one standard deviation increase in the CTC parameter ( 0.0223 see Table 5 in the Appendix) results in $7.1 \%$ decrease in the reported profits.

In column 2 we explore whether adding back negative profits would have any effect on the magnitude of the estimated coefficients. To do so, we define a new dependent variable that takes value zero for all observations with zero or negative profit and loss before taxes and takes value $\log \left(R \pi_{i}\right)$ otherwise. In Column 2 we estimate a model with this new variable, which is censored at zero using panel data Tobit specification. We find that the coefficient on the CTC parameter is smaller in this specification, but not significantly so. This reassures us that the results are not driven only by the positive profits part of the profits distribution.

In column 3 we explore the possibility of making corruption a firm specific variable. To do this we use the average corruption rate amongst companies belonging to the same GUO and the GUO corruption rate itself and use that in the definition of the CTC parameter itself. Hence, instead of adjusting tax rate differential by the corruption in the country where the profits are reported, now the tax rate differential is adjusted by the average of all corruption rates in all countries of subsidiaries belonging to the same parent company and the corruption in the country of the parent

\footnotetext{
${ }^{38}$ We know that the share of profits shifted should be $\hat{\beta}_{5} \cdot$ CTC. Hence $C T C_{A V, C}=.162$ implies a $15.7 \%$ profits inflow and $C T C_{A V, C}=-.191$ a $18.6 \%$ profits outflow.
} 
company. Therefore, corruption is a firm specific variable in those specifications. This increases the size of the coefficient on the CTC parameter slightly, from -0.92 to -0.99 , but this change is not statistically significant.

The results from columns $4-7$ show that the results using the CTC parameter are driven jointly by corruption and tax rate differentials. Further, they also address Proposition 1 directly, by showing how corruption affects the relationship between tax rate differentials and reported profits. Here, we use an alternative estimation approach, in which, instead of using the CTC parameter as one of the regressors, we use logarithm of control of corruption and tax rate differentials separately and include an interaction effect between the two. ${ }^{39}$ Hence, we estimate the following

$$
\begin{aligned}
\log \left(R \pi_{i}\right)=\beta_{1} & +\beta_{2} \cdot \log (a)+\beta_{3} \cdot \log \left(L_{i}\right)+\beta_{4} \cdot \log \left(K_{i}\right)+\beta_{5} \cdot \Delta t_{i}+\beta_{6} \cdot c_{i} \\
& +\beta_{7} \cdot \Delta t_{i} \times c_{i}+u_{i} .
\end{aligned}
$$

The findings presented in columns $4-7$ in are in line with what our theory model predicts. The larger the difference between tax rates in the country where the firm is located and the tax rates abroad, the lower the profits reported by that particular firm. Further, the interaction between tax and corruption is also statistically significant and suggests that corruption has an effect on how tax rate differentials between firms affect reported profits. The more corrupt the country is, the larger the effect the tax differential has on reported profits. In other words, corruption amplifies profitshifting incentives, as predicted by Proposition 1.

However, we should interpret these results with caution. This is because the theoretical model implies a non-linear joint effect of corruption and taxation on profit shifting. Therefore, separately estimating the effects of corruption and tax rate differentials may mean that the model may be missspecified. ${ }^{40}$

\footnotetext{
${ }^{39}$ Online Appendix B.1. presents the theoretical underpinning for the alternative estimation equation.

${ }^{40}$ We discus additional findings in the Online Appendix. Appendix A talks about the role of intangible assets. Appendix B discuses additional factors that might influence our main results, like the corruption outside the tax administration, the level of government quality and the location choices of a multinational firm.
} 
TABLE 2 RoBUSTNESS

\begin{tabular}{lccccccc}
\hline Definitions of & $(1)$ & $(2)$ & $(3)$ & $(4)$ & $(5)$ & $(6)$ & $(7)$ \\
CTC & $C T C_{A V, C}$ & $C T C_{A V, C}$ & $C T C_{A V, C}$ & $C T C_{A V, C}$ & $C T C_{H Q}$ & $C T C_{H A V E N}$ & $C T C_{A V, C}$ \\
\hline \multirow{3}{*}{ capital } & & & & & & & \\
& $0.134^{* * *}$ & $-0.065^{* * *}$ & $0.067^{* * *}$ & $0.070^{* * *}$ & $0.071^{* * *}$ & $0.198^{* * *}$ & $0.134^{* * *}$ \\
labour & $(0.009)$ & $(0.003)$ & $(0.003)$ & $(0.003)$ & $(0.003)$ & $(0.002)$ & $(0.009)$ \\
& $0.354^{* * *}$ & $0.667^{* * *}$ & $0.316^{* * *}$ & $0.330^{* * *}$ & $0.330^{* * *}$ & $0.430^{* * *}$ & $0.351^{* * *}$ \\
$\log (\mathrm{GDPpC})$ & $(0.018)$ & $(0.005)$ & $(0.006)$ & $(0.006)$ & $(0.006)$ & $(0.003)$ & $(0.018)$ \\
& $1.331^{* * *}$ & $0.049^{* * *}$ & $1.234^{* * *}$ & $1.151^{* * *}$ & $1.143^{* * *}$ & $1.087^{* * *}$ & $1.211^{* * *}$ \\
CTC & $(0.189)$ & $(0.008)$ & $(0.057)$ & $(0.055)$ & $(0.055)$ & $(0.054)$ & $(0.192)$ \\
& $-3.205^{* * * *}$ & $-0.815^{* * *}$ & $-0.985^{* * *}$ & & & & \\
$\Delta t$ & $(0.755)$ & $(0.248)$ & $(0.252)$ & & & & \\
& & & & $-2.188^{* * *}$ & $-1.229^{* * *}$ & $-0.213^{* * *}$ & $-3.798^{* * *}$ \\
control of Corr. & & & & $(0.339)$ & $(0.203)$ & $(0.023)$ & $(0.870)$ \\
& & & & $0.159^{* *}$ & $0.180^{* * *}$ & $0.397^{* * *}$ & $0.408^{* * *}$ \\
$\Delta t$ ×control & & & & $(0.068)$ & $(0.067)$ & $(0.067)$ & $(0.125)$ \\
of Corr. & & & & $2.800^{* * *}$ & $1.066^{* * *}$ & $0.288^{* * *}$ & $2.812^{* * *}$ \\
Constant & $-11.53^{* * * *}$ & $0.558^{* * *}$ & $-9.177^{* * *}$ & $-8.504^{* * *}$ & $-8.421^{* * *}$ & $-8.795^{* * *}$ & $-10.503^{* * *}$ \\
& $(2.024)$ & $(0.084)$ & $(0.604)$ & $(0.565)$ & $(0.563)$ & $(0.548)$ & $(2.045)$ \\
\#Observations & 66,354 & 919,766 & 505,522 & 605,399 & 605,543 & 716,539 & 66,354 \\
\#Firms & 44,554 & 187,446 & 136,293 & 152,997 & 153,050 & 181,359 & 44,554 \\
R-squared & 0.091 & & 0.032 & 0.035 & 0.035 & 0.506 & 0.091 \\
\hline
\end{tabular}

Note: Dependent variable: $\ln (\mathrm{pbt})$. Standard errors are clustered at the corporate group and country level, $(* * *) \mathrm{p}<0.01$, (**) $\mathrm{p}<0.05$, (*) $\mathrm{p}<0.1$. Columns (1), (2), (3), (4) and (7) use $\Delta t_{A V, C}$, column (5) $\Delta t_{H Q}$ and column (6) $d \Delta t_{H A V E N}$ as a proxy for tax rate difference. Columns (1) and (7) use the WB business survey measure of corruption in the tax administration while the others use the WGI corruption indicator. In column (2) the missing values of $\ln (\mathrm{pbt}$ are replaced by zeros if pbt was negative or zero. In column (3) CTC is weighted by the average corruption across all firm subsidiary locations. Columns (4) and (7) proxy the CTC by an interaction term between the tax rate difference and the level of domestic control of corruption, hence they estimate [18] instead of [17]. All estimates include firm and year fixed effects except column (6) that uses country and year fixed effects.

\subsection{IMPLIED DOMESTIC TAX REVENUE ELASTICITIES}

In this section we use the estimated coefficients on the CTC parameter to calculate tax revenue elasticities with respect to the top statutory tax rates for each country in the sample. Using the estimate of the effect of CTC on reported profits from Column 2 in Table 1 we can calculate $\gamma=$ $1 /[-0.972]=1.03$. This, together with the firm level data for European firms, allows us to simulate the elasticity of reported profits with respect to the top statutory tax rate for different countries. To do so we first calculate the actual profit of each firm. From [12] we obtain 


$$
\pi_{i}=\frac{R \pi_{i}}{\left[1-\frac{\Delta t_{i}}{\gamma \cdot\left[1+c_{i}\right]}\right]}
$$

Then we calculate the profit that would be reported in country $j$ by firm $i$, if the statutory tax rate increases by one percentage point. From [12] we obtain

$$
R \pi_{i, t+0,01}=\pi_{i}\left[1-\frac{\Delta t_{j}+0.01}{\gamma \cdot\left[1+c_{j}\right]}\right] .
$$

From this, we can calculate the sum of the changes in reported profit for all firms $i$ that are located in country $j$ as follows

$$
d R \pi_{j}=\sum_{i}^{l}\left[R \pi_{i, t+0,01}-R \pi_{i, t}\right] d t_{j}
$$

where $l$ is the number of firms belonging to country $j$. Using this, we calculate the tax revenue elasticity with respect to the top statutory tax to be

$$
\frac{d R \pi_{j}}{d t_{j}} \frac{t_{j}}{\sum_{i}^{n}\left[R \pi_{i, t}\right]}+1 .
$$

The tax revenue elasticity tells us the percentage change in tax collected from all firms in country $j$, given a one percent change in the tax rate of country $j$. Hence, the tax revenue elasticities represent revenue gains in response to changes in statutory tax rates. Obtaining correct estimates of tax revenue elasticities is important, especially in the light of the financial crisis recovery and proposals by some countries to raise their tax revenues by increasing their tax rates. Specifically, Greece has suggested that an increase in their statutory tax rate would raise required revenues.

We calculate the tax revenue elasticities for the year 2013 for all European countries in our sample. ${ }^{41}$ The results are presented in Figure 3, where each dot represents a country. On the vertical axis we have tax revenue elasticities and on the horizontal axis we have control of corruption. Therefore, the plot shows how tax revenue elasticities change with an increase in control of corruption. The plotted elasticities are grouped into three different clusters, according to their statutory tax rates; triangles represent countries with low statutory tax rates $(0.05-0.15)$, circles

41 The underlying data for Figure 3 is summarized in Table 6 in the Appendix. 
represent countries with medium statutory tax rates $(0.15-0.25)$ and squares represent countries with high statutory tax $(0.25-0.35) .{ }^{42}$

All countries have absolute elasticities below 1, but larger than zero. Hence, no country has a tax rate that is Laffer inefficient. Within each group of tax rates, the tax revenue elasticities are an increasing function of control of corruption. This means that countries with otherwise similar tax rates face lower tax revenue elasticities when they are more corrupt. Thus, corruption decreases the possible gains that countries could have from tax rate increases. For instance, a tax rate increase of $1 \%$ in Portugal increases tax revenue by $0.84 \%$, while a tax rate increase of $1 \%$ in Netherlands increases tax revenue by $0.86 \%$. This means that Portugal may lose up to approximately $2 \%$ of their tax revenue due to corruption. This effect is even starker when we compare Italy and Norway. A similar $1 \%$ increase in tax rate will increase tax revenues by 0.79 percent in Italy and by 0.86 percent in Norway. ${ }^{43}$ In other words, a decrease of the level of corruption to the level of Norway might induce a tax revenue gain of over 7\% in Italy, absent behavioral effects.

The calculated tax revenue elasticities imply that countries such as Greece and Italy would face the largest difficulties in raising tax revenue through increasing their tax rates on profits. This is the case as both countries already have high tax rates and face high levels of corruption. On the other hand, tax rate cuts by these countries would have less of a negative effect on the total revenue collected, than in case of countries with lower corruption levels.

Specifically, in the light of the recently proposed reforms to the statutory tax rate in the UK and Italy we will see the UK tax rate decrease from 20\% in 2015 to 17\% in 2020, whereas the Italian tax rate will decrease from 30\% in 2015 to $26 \%$ in 2020. Using our elasticity estimates, the cut to the UK tax rate by $11 \%$ will decrease its revenues by $10 \%$ while a $15 \%$ cut to the tax rate in Italy will reduce its tax revenues by $12 \% .{ }^{44}$

\footnotetext{
${ }^{42}$ For a comparison of the corruption adjusted elasticities with non-corruption adjusted ones, which are standard in the literature, see Figure 5 in the Appendix. The elasticities estimated in this paper are smaller and have larger variance than the previously estimated ones.

${ }^{43}$ A possible concern here may be that this effect could also be the result of differences in the exposure of firms to profit shifting opportunities and not differences in the level of corruption. We show this is not the case. In Figure 5 in the Appendix we compare tax revenue elasticities that account for corruption, with tax revenue elasticities as calculated by the previous literature. The results show that corruption decreases tax revenue elasticities.

${ }^{44}$ The tax revenue elasticities will differ slightly depending on the definition of the CTC parameter used. Figure 6 in the Appendix shows the mean, maximum and minimum tax revenue elasticities implied by the estimates from Table 1 Columns 2-4. The approximation of $C T C$ by $C T C_{A V, C}$ used to calculate the baseline elasticities in this paper is the lower
} 


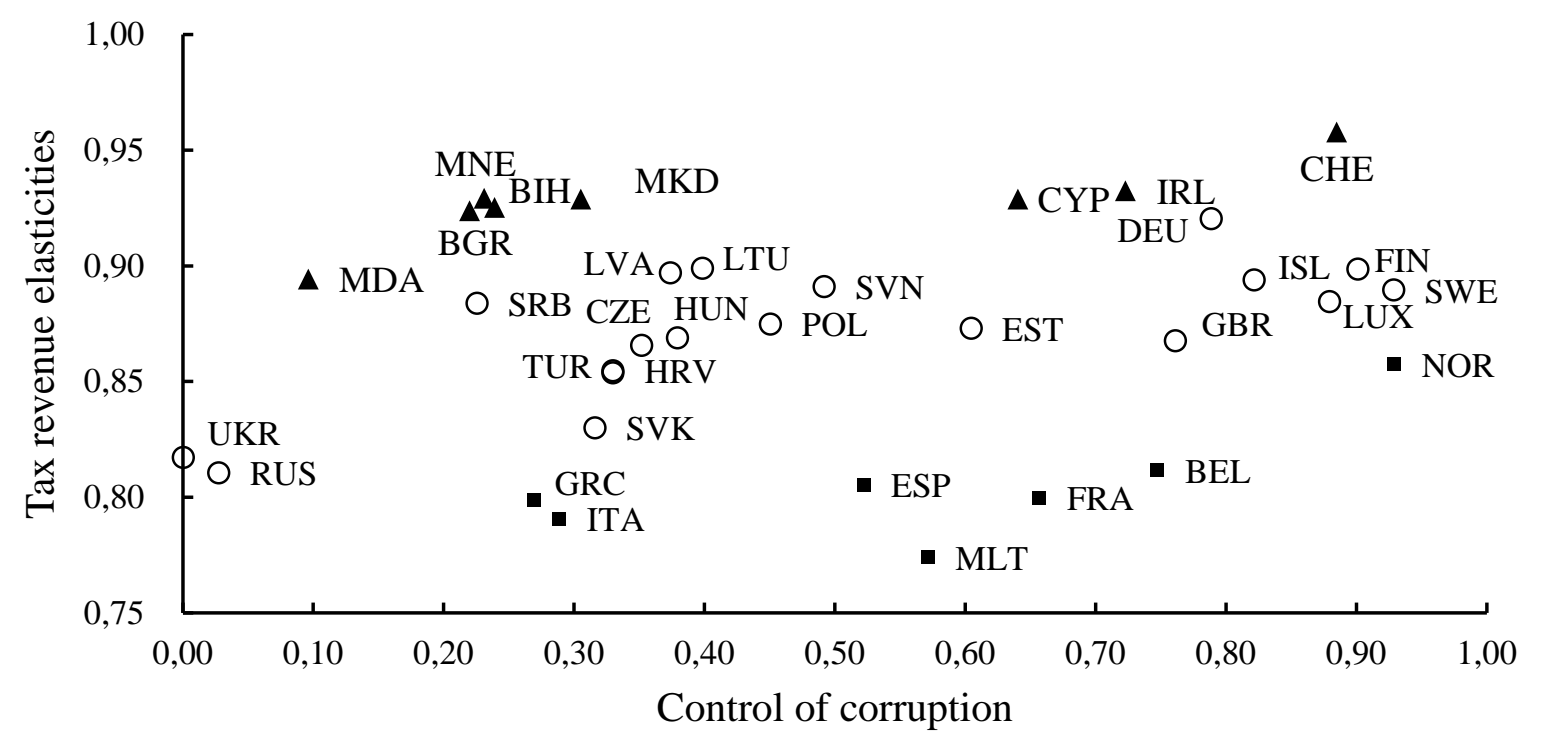

$\Delta$ Low Tax Country (0.05-0.15) O Med Tax Country (0.15-0.25) • Hig Tax Country (0.25-0.35)

Figure 3 Semi-elasticity of reported profits with respect to the top statutory tax rate

\section{CONCLUSION}

Our analysis has revealed that corruption amplifies profit shifting. Multinationals that have an incentive to shift profits, will shift more profits with higher corruption in the tax administration. Our theoretical model implies that this is because corruption decreases the cost of profit shifting. Corrupt tax officials have an incentive to collect bribes for reducing the tax auditing costs of firms.

Accounting for the effect of corruption on profit shifting of multinational firms reveals a substantially larger heterogeneity of tax elasticities even within Europe. Countries with similar tax rates face considerably different tax elasticities when the extent of corruption differs between them. On average, countries with high levels of corruption face lower tax revenue elasticities with respect to tax rates. Therefore, tax rate increases lead to much smaller tax revenue increases in corrupt countries. These results imply that a country with a persistent corruption problem might be unable to generate large tax revenues by taxing profits of multinational firms.

These results highlight that when fighting international tax avoidance, we should account for the heterogeneity in the quality of enforcement institutions. In particular, an intensified fight against corruption in the tax administration should accompany increases in the tax rates. To be more

bound estimate. For instance, tax revenue elasticities can be as low as 0.64 for Italy and 0.76 for Norway. This would imply that Italy may even be losing up to $12 \%$ of its tax revenues due to corruption. 
specific, first, high tax countries may want to consider offering countries that face high levels of corruption something in return when demanding that they harmonize their tax rates and invest in the fight against profit sifting, for example, by implementing the BEPS action plan. In comparison to countries where there is little corruption accompanying the enforcement of taxation, these countries lose much more tax revenue when complying with the international tax regime.

Second, intensified fight against tax havens may be one of the most important means for developing countries that struggle with high levels of corruption in their tax administration to foster growth in tax revenues. As our paper shows, a decrease in the international tax sheltering opportunities increases revenue collection substantially in those countries. This could potentially free revenues that, in turn, can be used to decrease corruption.

\section{ACKNOWLEDGEMENTS}

We would like to thank Michael Devereux, Marcel Thum, Alexander Kemnitz and participants of the IIPF 2016 meeting for their helpful comments and suggestions. Financial support from the Deutsche Forschungsgemeinschaft (Grant 759-3) is gratefully acknowledged.

\section{REFERENCES}

Alm, J., Martinez-Vazquez, J., \& McClellan, C. (2016). Corruption and Firm Tax Evasion. Journal of Economic Behavior and Organization, Forthcoming.

Becker, J., \& Davies, R. B. (2014). A negotiation-based model of tax-induced transfer pricing. CESifo Working Papers No. 4892.

Beer, S., \& Loeprick, J. (2015). Profit shifting: drivers of transfer (mis) pricing and the potential of countermeasures. International Tax and Public Finance, 22(3), 426-451.

Besley, T., \& McLaren, J. (1993). Taxes and bribery: the role of wage incentives. The Economic Journal, 103(416), 119-141.

Bilicka, K. (2019). Comparing UK Tax Returns of Foreign Multinationals to Matched Domestic Firms. American Economic Review, 109(8), 2921-53.

Bilicka, K., \& Fuest, C. (2014). With which countries do tax havens share information? International Tax and Public Finance, 21(2), 175-197.

Bilicka, K., Devereux, M., \& Guceri. (2019). Optimization Frictions and Fixed Costs of Profit Shifting. Unpublished Manuscript. 
Chander, P., \& Wilde, L. (1992). Corruption in tax administration. Journal of Public Economics, 49(3), 333-349.

Chen, K., \& Chu, C. (2005). Internal control versus external manipulation: a model of corporate income tax evasion. RAND Journal of Economics, 36(1), 151-164.

Cristea, A. D., \& Nguyen, D. X. (2016). Transfer pricing by multinational firms: New evidence from foreign firm ownerships. American Economic Journal: Economic Policy, 3, 170-202.

Crocker, K., \& Slemrod, J. (2005). Corporate tax evasion with agency costs. Journal of Public Economics, 89(9-10), 1593-1610.

Davies, R. B., Martin, J., Parenti, M., \& Toubal, F. (2018). Knocking on Tax Haven's Door: Multinational Firms and Transfer Pricing. The Review of Economics and Statistics, forthcoming .doi:10.1162/REST_a_00673

Desai, M. A., Foley, C. F., \& Hines Jr, J. R. (2006). The demand for tax haven operations. Journal of Public economics, 90(3), 513-531.

Desai, M. A., Foley, C. F., \& Hines, \&. (2004). A multinational perspective on capital structure choice and internal capital markets. The Journal of Finance, 59(6), 2451-2487.

Dharmapala, D. (2014). What Do We Know about Base Erosion and Profit Shifting? A Review of the Empirical Literature. Fiscal Studies, 35(4), 421-448.

Dharmapala, D., \& Riedel, N. (2013). Earnings shocks and tax-motivated income-shifting: Evidence from European multinationals. Journal of Public Economics, 97(1), 95-107.

Dischinger, M., \& Riedel, N. (2011). Corporate taxes and the location of intangible assets within multinational firms. Journal of Public Economics, 95(7), 691-707.

Dischinger, M., Knoll, B., \& Riedel, N. (2014). There's no place like home: The profitability gap between headquarters and their foreign subsidiaries. Journal of Economics \& Management Strategy, 23(2), 369-395.

Dowd, T., Landefeld, P., \& Moore, A. (2017). Profit shifting of US multinationals. Journal of Public Economics, 148, 1-13.

Flatters, F., \& Macleod, W. (1995). Administrative corruption and taxation. International Tax and Public Finance, 2(3), 397-417.

Fuest, C., Hebous, S., \& Riedel, N. (2011). International debt shifting and multinational firms in developing economies. Economics Letters, 113(2), 135-138.

Gauthier, B., \& Goyette, J. (2014). Taxation and corruption: theory and firm-level evidence from Uganda. Applied Economics, 46(23), 2755-2765. 
Gumpert, A., Hines Jr, J. R., \& Schnitzer, M. (2016). Multinational firms and tax havens. Review of Economics and Statistics, 98(4), 713-727.

Hebous, S., \& Lipatov, V. (2014). A journey from a corruption port to a tax haven. Journal of Comparative Economics, 42(3), 739-754.

Heckemeyer, J. H., \& Overesch, M. (2017). Multinationals’ profit response to tax differentials: Effect size and shifting channels. Canadian Journal of Economics, 4, 965-994.

Hindriks, J., Keen, M., \& Muthoo, A. (1999). Corruption, extortion and evasion. Journal of Public Economics, 74(3), 395-430.

Hines, J. R., \& Rice, E. M. (1994). Fiscal paradise: foreign tax havens and American business. Quarterly Journal of Economics, 109(1), 149-182.

Huizinga, H., \& Laeve, L. (2008). International profit shifting within multinationals: A multicountry perspective. Journal of Public Economics, 92(5), 1164-1182.

Jagger, P., \& Shively, G. (2015). Taxes and Bribes in Uganda. The Journal of Development Studies, 51(1), 66-79.

Janský, P., \& Palanský, M. (2019). Estimating the scale of profit shifting and tax revenue losses related to foreign direct investment. International Tax and Public Finance, 26(5), 10481103.

Johannesen, N., Tørsløv, T., \& Wier, L. (2017). Are less developed countrie more exposed to multinational tax avoidance? WIDER Working Paper 2017/05.

Kaufmann, D., Kraay, A., \& Mastruzzi, M. (2005). Governance Matters IV: Governance Indicators for 1996-2004. World Bank Policy Research Working Paper No. 3630. Retrieved from SSRN: https://ssrn.com/abstract=718081 or http://dx.doi.org/10.

Khan, A., Khwaja, A., \& Olken, B. (2016). Tax Farming Redux: Experimental Evidence on Performance Pay for Tax Collectors. Quarterly Journal of Economics, 131(1), 219-271.

Koethenbuerger, M., Mardan, M., \& Stimmelmayr, M. (2019). Profit shifting and investment effects: The implications of zero-taxable profits. Journal of Public Economics, 173, 96112.

Konrad, K. A., \& Stolper, T. B. (2016). Coordination and the fight against tax havens. Journal of International Economics, 103, 96 -107.

Lohse, T., \& Riedel, N. (2013). Do transfer pricing laws limit international income shifting? Evidence from European multinationals. CESifo working paper no. 4404. 
Marjit, S., Mukherjee, V., \& Mukherjee, A. (2000). Harassment, corruption and tax policy. European Journal of Political Economy, 16(1), 75-94.

Marjit, S., Seidel, A., \& Thum, M. (2017). Tax Evasion, Corruption and Tax Loopholes. German Economic Review, 18(3), 283-301.

Mookherjee, D., \& Png, I. (1995). Corruptible law enforcers: How should they be compensated? Economic Journal, 105(428), 145-159.

Seidel, A., \& Thum, M. (2016). Tax Evasion, Corruption and Market Entry. Scottish Journal of Political Economy, 63(4), 377-398.

Tørsløv, T. R., Wier, L. S., \& Zucman, G. (2018). The missing profits of nations. (No. w24701) National Bureau of Economic Research . 


\section{APPENDIX. SUPPLEMENTARY TABLES AND FIGURES}

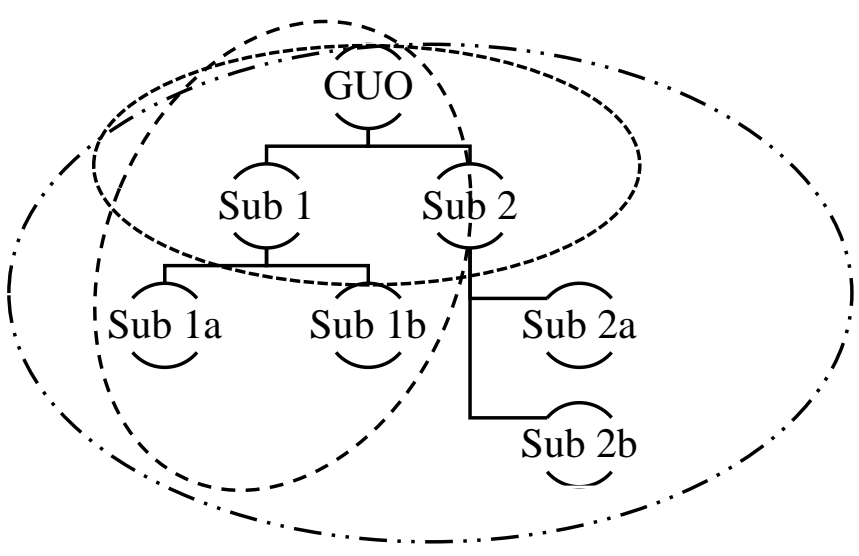

Figure 4 Definition of different relevant profit shifting groups: A ----.; B - - -; C _ ..

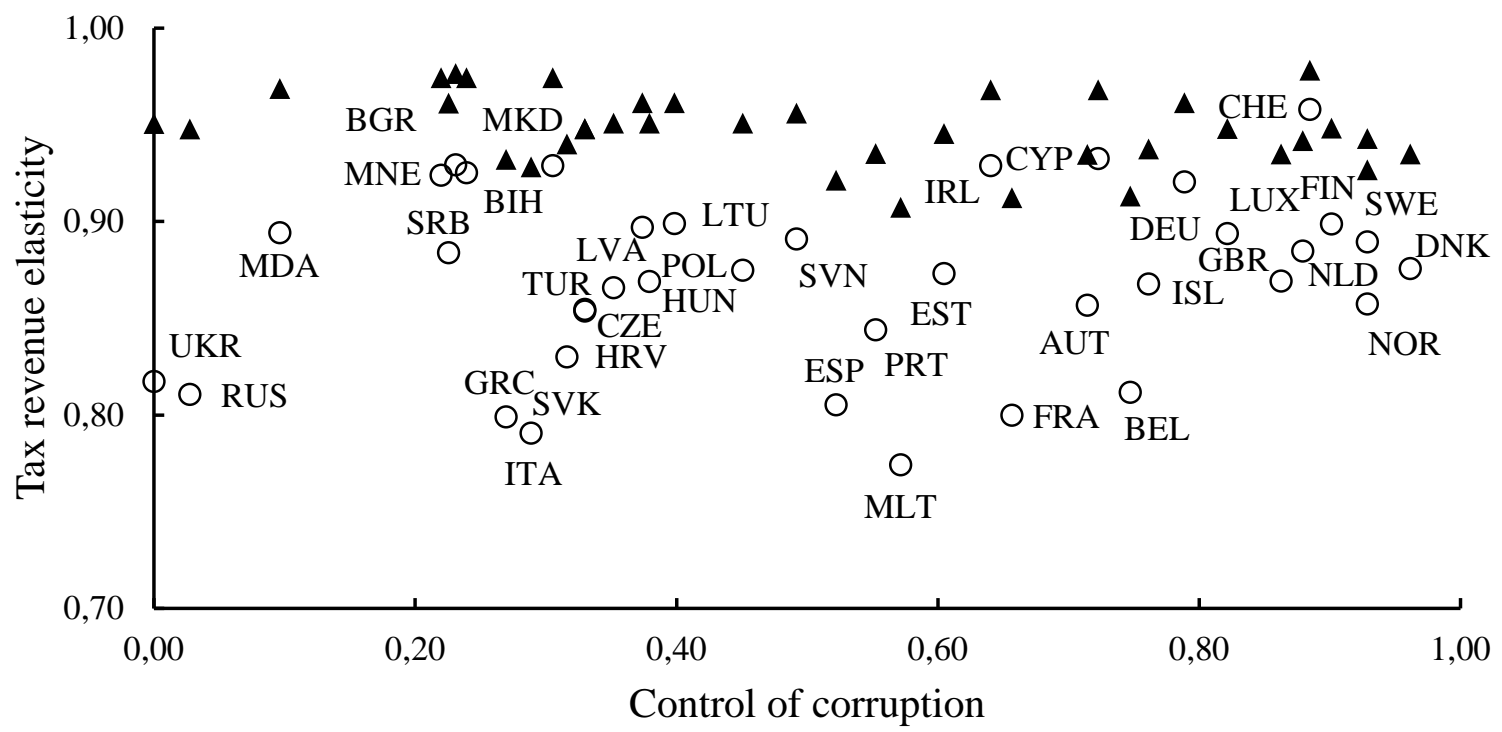

O Corruption adjusted tax revenue elasticities

$\Delta$ Not corruption adjusted tax revenue elasticities

Figure 5 Tax revenue elasticities with respect to the top statutory tax rate. 


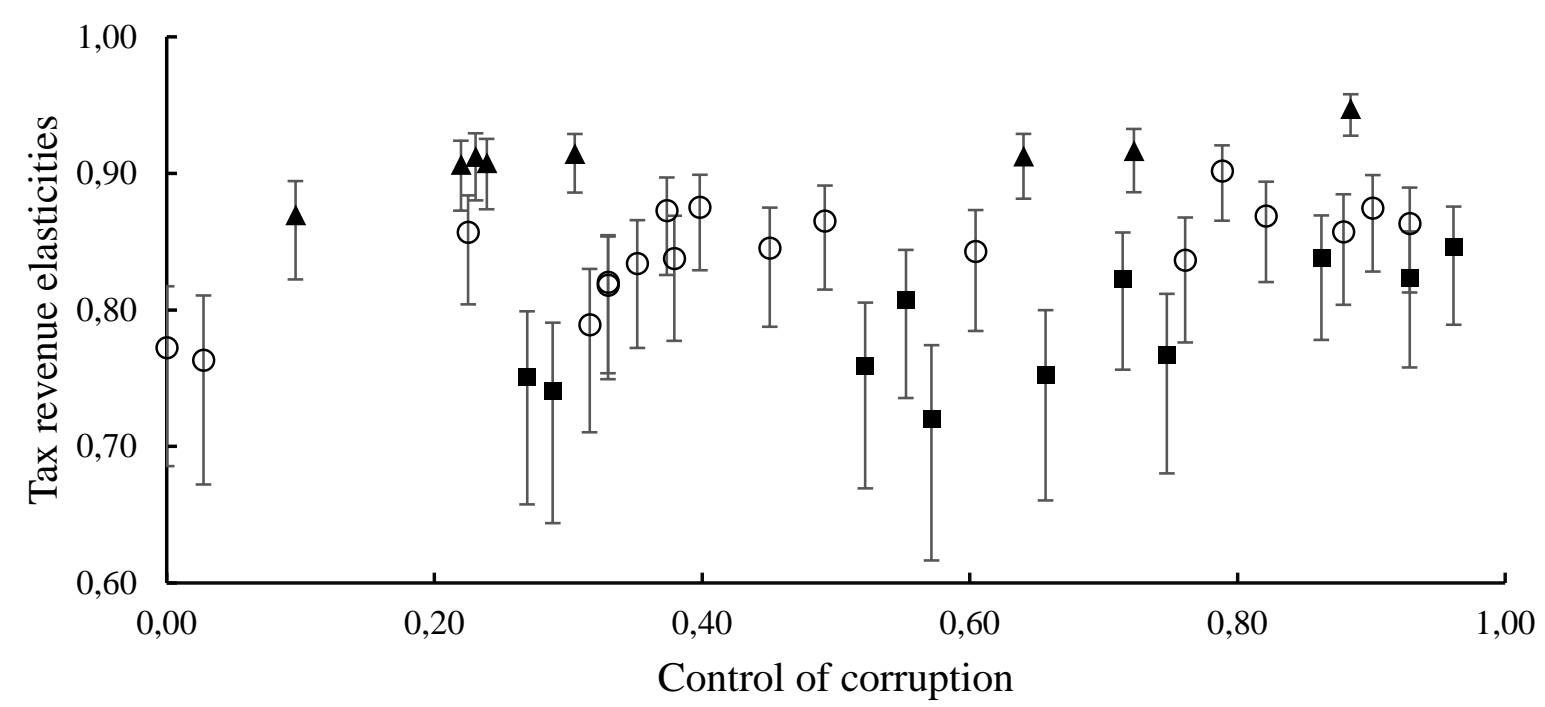

$\Delta$ Low Tax Country [0.05-0.15[ O Low Tax Country [0.15-0.25[ a Hig Tax Country [0.25-0.35]

Figure 6 Variation in the implied tax revenue elasticities (Table 1 Colum 2 to 4).

TABLE 3: DATA SOURCES.

\begin{tabular}{|c|c|c|}
\hline Variable & Data source & Data link \\
\hline Control of corruption & $\begin{array}{l}\text { World Bank Governance } \\
\text { Indicators }\end{array}$ & $\begin{array}{l}\text { http://info.worldbank.org/governance/ } \\
\text { wgi/\#home }\end{array}$ \\
\hline $\begin{array}{l}\text { Control of corruption in tax } \\
\text { administration }\end{array}$ & WBES survey & $\begin{array}{l}\text { https://data.worldbank.org/data- } \\
\text { catalog/enterprise-surveys }\end{array}$ \\
\hline Statutory corporate tax rate & CBT Tax Database & $\begin{array}{l}\text { https://www.sbs.ox.ac.uk/faculty- } \\
\text { research/tax/publications/data }\end{array}$ \\
\hline Profits, capital, labour & AMADEUS & BvD Data link through Oxford library \\
\hline Costs of starting a business & $\begin{array}{l}\text { World Bank Doing } \\
\text { Business Survey }\end{array}$ & $\begin{array}{l}\text { http://www.doingbusiness.org/Custom } \\
\text {-Query }\end{array}$ \\
\hline
\end{tabular}


TABLE 4 DESCRIPTIVE STATISTICS

\begin{tabular}{|c|c|c|c|c|c|}
\hline Variable & \#Obs. & Mean & Std. Dev. & Min & Max \\
\hline statutory tax rate & 757,127 & 0.247 & 0.063 & 0 & 0.350 \\
\hline control of corruption & 721,320 & 0.517 & 0.254 & 0 & 1 \\
\hline corruption in tax admin. & 94,285 & 13.230 & 15.556 & 0 & 67.600 \\
\hline $\operatorname{lnGDPpc}$ & 730,154 & 10.656 & 1.027 & 7.216 & 15.533 \\
\hline lnpbt & 757,127 & 4.956 & 2.005 & 0 & 8.005 \\
\hline capital & 757,127 & 5.745 & 2.536 & 0 & 18.475 \\
\hline labor & 757,127 & 2.969 & 1.589 & 0 & 10.942 \\
\hline \multicolumn{6}{|c|}{$\begin{array}{l}\text { Note: Source: Firm level data is from BvD AMADEUS, corruption indicators from WB, tax rates from the CBT tax } \\
\text { database. }\end{array}$} \\
\hline \multicolumn{6}{|c|}{ TABLE 5 DESCRIPTIVE STATISTICS ON TAX DIFFERENTIALS } \\
\hline Variable & \#Obs. & Mean & Std. Dev. & Min & Max \\
\hline$C T C_{H Q}$ & 605,549 & 0.002 & 0.059 & -0.267 & 0.246 \\
\hline$C T C_{H A V E N}$ & 721,320 & 0,065 & 0.210 & 0 & 1 \\
\hline$C T C_{A V . A}$ & 605,405 & 0 & 0.031 & -0.191 & 0.163 \\
\hline$C T C_{A V . B}$ & 605,405 & 0.002 & 0.029 & -0.135 & 0.139 \\
\hline$C T C_{A V, C}$ & 605,405 & 0 & 0.027 & -0.191 & 0.162 \\
\hline$C T C_{A V, C}$ (WB Survey) & 66,354 & -.007 & .023 & -0.162 & 0.128 \\
\hline
\end{tabular}

Note: Source: Tax data from the CBT tax database. 
TABle 6 Aggregate TAX REVEnUE Elasticities FOR 2013.

\begin{tabular}{|c|c|c|c|c|c|c|c|}
\hline Country & $\begin{array}{l}\text { Statutory } \\
\text { tax rate }\end{array}$ & $\begin{array}{l}\text { Control of } \\
\text { corruption }\end{array}$ & Elasticity & Country & $\begin{array}{l}\text { Statutory } \\
\text { tax rate }\end{array}$ & $\begin{array}{l}\text { Control of } \\
\text { corruption }\end{array}$ & Elasticity \\
\hline AUT & 0.250 & 0.714 & 0,857 & ITA & 0.275 & 0.288 & 0,791 \\
\hline BEL & 0.330 & 0.747 & 0,812 & LTU & 0.150 & 0.398 & 0,899 \\
\hline BGR & 0.100 & 0.220 & 0,924 & LUX & 0.225 & 0.879 & 0,885 \\
\hline $\mathrm{BIH}$ & 0.100 & 0.239 & 0,925 & LVA & 0.150 & 0.374 & 0,897 \\
\hline CHE & 0.085 & 0.885 & 0,958 & MDA & 0.120 & 0.096 & 0,894 \\
\hline CYP & 0.125 & 0.640 & 0,929 & MKD & 0.100 & 0.305 & 0,929 \\
\hline CZE & 0.190 & 0.352 & 0,866 & MLT & 0.350 & 0.571 & 0,774 \\
\hline DEU & 0.150 & 0.788 & 0,921 & MNE & 0.090 & 0.231 & 0,929 \\
\hline DNK & 0.250 & 0.962 & 0,876 & NLD & 0.250 & 0.863 & 0,869 \\
\hline ESP & 0.300 & 0.522 & 0,805 & NOR & 0.280 & 0.929 & 0,857 \\
\hline $\mathrm{EST}$ & 0.210 & 0.604 & 0,873 & POL & 0.190 & 0.451 & 0,875 \\
\hline FIN & 0.200 & 0.901 & 0,899 & PRT & 0.250 & 0.552 & 0,844 \\
\hline FRA & 0.333 & 0.657 & 0,800 & RUS & 0.200 & 0.027 & 0,811 \\
\hline GBR & 0.240 & 0.761 & 0,868 & SRB & 0.150 & 0.225 & 0,884 \\
\hline GRC & 0.260 & 0.269 & 0,799 & SVK & 0.230 & 0.316 & 0,830 \\
\hline HRV & 0.200 & 0.330 & 0,855 & SVN & 0.170 & 0.492 & 0,891 \\
\hline HUN & 0.190 & 0.379 & 0,869 & SWE & 0.220 & 0.929 & 0,890 \\
\hline IRL & 0.125 & 0.723 & 0,933 & TUR & 0.200 & 0.330 & 0,854 \\
\hline ISL & 0.200 & 0.821 & 0,894 & UKR & 0.190 & 0.000 & 0,817 \\
\hline
\end{tabular}


TABLE 7 LIST OF COUNTRIES AND MEAN VALUES OF CORRUPTION INDICATORS.

\begin{tabular}{|c|c|c|c|c|c|c|}
\hline \multirow{2}{*}{$\begin{array}{l}\text { Country } \\
\text { ISO code }\end{array}$} & \multicolumn{3}{|c|}{ WGI } & \multicolumn{3}{|c|}{ WBES } \\
\hline & Mean & Std. Dev. & Freq. & Mean & Std. Dev. & Freq. \\
\hline $\mathrm{AT}$ & 0.77 & 0.07 & 24,357 & & & \\
\hline BA & 0.21 & 0.02 & 6,799 & 0.85 & 0.24 & 2,114 \\
\hline $\mathrm{BE}$ & 0.70 & 0.03 & 121,627 & & & \\
\hline BG & 0.24 & 0.02 & 17,108 & 0.89 & 0.12 & 7,067 \\
\hline $\mathrm{CH}$ & 0.88 & 0.01 & 328 & & & \\
\hline CY & 0.59 & 0.04 & 166 & & & \\
\hline $\mathrm{CZ}$ & 0.38 & 0.02 & 80,802 & 0.92 & 0.15 & 24,915 \\
\hline $\mathrm{DE}$ & 0.78 & 0.01 & 96,185 & 0.85 & - & 7,456 \\
\hline DK & 0.97 & 0.01 & 49,250 & & & \\
\hline $\mathrm{EE}$ & 0.56 & 0.02 & 24,814 & 0.97 & 0.06 & 8,087 \\
\hline ES & 0.58 & 0.03 & 151,124 & 0.86 & - & 13,285 \\
\hline FI & 0.93 & 0.03 & 34,856 & & & \\
\hline FR & 0.69 & 0.02 & 254,699 & & & \\
\hline GB & 0.76 & 0.03 & 300,713 & & & \\
\hline GR & 0.31 & 0.06 & 11,815 & 0.44 & - & 1,118 \\
\hline HR & 0.30 & 0.02 & 248,047 & 0.93 & 0.08 & 71,373 \\
\hline $\mathrm{HU}$ & 0.40 & 0.04 & 16,411 & 0.94 & 0.10 & 5,670 \\
\hline IE & 0.75 & 0.03 & 26,691 & 0.89 & - & 1,733 \\
\hline IS & 0.87 & 0.06 & 7,057 & & & \\
\hline IT & 0.34 & 0.05 & 242,577 & & & \\
\hline LI & 0.72 & 0.08 & 24 & & & \\
\hline $\mathrm{LT}$ & 0.35 & 0.03 & 6,368 & 0.84 & 0.13 & 1,868 \\
\hline LU & 0.86 & 0.03 & 16,605 & & & \\
\hline LV & 0.35 & 0.02 & 16,763 & 0.95 & 0.10 & 4,939 \\
\hline MD & 0.12 & 0.01 & 371 & 0.76 & 0.14 & 124 \\
\hline $\mathrm{ME}$ & 0.23 & - & 6 & 0.95 & 0.05 & 39 \\
\hline MK & 0.27 & 0.04 & 192 & 0.91 & 0.09 & 54 \\
\hline MT & 0.55 & 0.02 & 4,853 & & & \\
\hline NL & 0.88 & 0.02 & 45,814 & & & \\
\hline $\mathrm{NO}$ & 0.88 & 0.04 & 72,332 & & & \\
\hline PL & 0.41 & 0.04 & 74,197 & 0.92 & 0.10 & 21,581 \\
\hline PT & 0.57 & 0.02 & 67,166 & 0.48 & - & 2,781 \\
\hline $\mathrm{RS}$ & 0.22 & 0.01 & 18,400 & 0.83 & 0.24 & 6,068 \\
\hline RU & 0.03 & 0.02 & 123,449 & 0.81 & 0.19 & 43,317 \\
\hline SE & 0.92 & 0.02 & 114,237 & 1.00 & - & 3,827 \\
\hline SI & 0.54 & 0.03 & 10,484 & 0.96 & 0.06 & 2,887 \\
\hline SK & 0.36 & 0.03 & 48,871 & 0.94 & 0.09 & 16,738 \\
\hline TR & 0.32 & 0.01 & 1,739 & 0.97 & 0.02 & 463 \\
\hline UA & 0.05 & 0.04 & 26,188 & 0.58 & 0.10 & 8,298 \\
\hline
\end{tabular}

Note: The WBES indicator was transformed to reflect the WGI control of corruption, hence it is 1 minus percent of firms expected to give gifts in meetings with tax official; e.g. 1.0 for Sweden means zero percent of bribes. 
TABLE 11 List OF TAX HAVENS.

$\begin{array}{lll}\text { Andorra } & \text { Ireland } & \text { Panama } \\ \text { Anguilla } & \text { Isle of Man } & \text { Saint Kitts and Nevis } \\ \text { Antigua and Barbuda } & \text { Jersey } & \text { Saint Lucia } \\ \text { Aruba } & \text { Liberia } & \text { Saint Martin (French part) } \\ \text { Bahamas } & \text { Liechtenstein } & \text { Saint Vincent and the } \\ \text { Bahrain } & \text { Luxembourg } & \text { Grenadines } \\ \text { Barbados } & \text { Macao } & \text { Samoa } \\ \text { Belize } & \text { Maldives } & \text { San Marino } \\ \text { Bermuda } & \text { Malta } & \text { Seychelles } \\ \text { Cayman Islands (the) } & \text { Marshall Islands (the) } & \text { Singapore } \\ \text { Cook Islands (the) } & \text { Mauritius } & \text { Switzerland } \\ \text { Cyprus } & \text { Monaco } & \text { Tonga } \\ \text { Dominica } & \text { Montserrat } & \text { Turks and Caicos Islands (the) } \\ \text { Gibraltar } & \text { Nauru } & \text { Vanuatu } \\ \text { Grenada } & \text { Netherlands (the) } & \text { Virgin Islands (British) } \\ \text { Guernsey } & \text { Netherlands Antilles } & \text { Virgin Islands (U.S.) } \\ \text { Hong Kong } & \text { Niue } & \end{array}$

